\title{
The Decoration of the Columns and Pillars from the Henket-ankh of Thutmose III (Western Thebes)
}

\author{
LINDA CHAPON
}

\begin{abstract}
The Temple of Millions of Years of Thutmose III called Henket-ankh, located on the West Bank of Thebes, was probably an important and impressive monument of which very little remains nowadays. Previous work at the site, which started already in the first half of the nineteenth century, contributed greatly to the understanding and identification of this complex. The Spanish-Egyptian project that resumed the archaeological works at the site in 2008 improved our knowledge about the temple architectural and decorative features. This paper will focus on the characteristics and decoration of the vertical architectural elements with support function, that is to say columns and pillars, may have had in this temple. The fragments and blocks examined and the few architectural elements preserved in situ have allowed ascertaining of the existence in the temple of polygonal columns with sixteen sides, squared pillars, some of which were of Osiride type, and circular columns that were most likely crowned by Hathoric capitals.
\end{abstract}

Keywords: New Kingdom Egypt, Henket-ankh, Temple of Millions of Years, architecture, decorative programme, pillar, column, Hathoric capital

Linda Chapon, Department of Prehistory and Archaeology, University of Granada, Granada;

lindachapon2002@hotmail.com; (D) 0000-0001-7066-8899

The Henket-ankh, the Temple of Millions of Years of Thutmose III located on the West Bank of Thebes was known at least from the second half of the eighteenth century. The first to carry out official work on the site was Georges Daressy in 1888 and $1889 .{ }^{1}$ However, only the excavations of Arthur E.P. Weigall ${ }^{2}$ allowed a definitive identification the Henket-ankh with the architectural remains that still exist today between el-Assasif and el-Khokha, just on the boundary between the arable land and the desert. ${ }^{3} \mathrm{~A}$ few decades later Herbert Ricke

${ }^{1}$ Daressy 1926.

2 Weigall 1906; 1907.

${ }^{3}$ Weigall 1906: 123-124. Weigall could only undertake a season of excavations between 1905 and 1906, but he managed to work in almost the entire building. This fact implies that the original context of all the reliefs and elements discovered in this area during current excavations was already altered due to his works. He published 

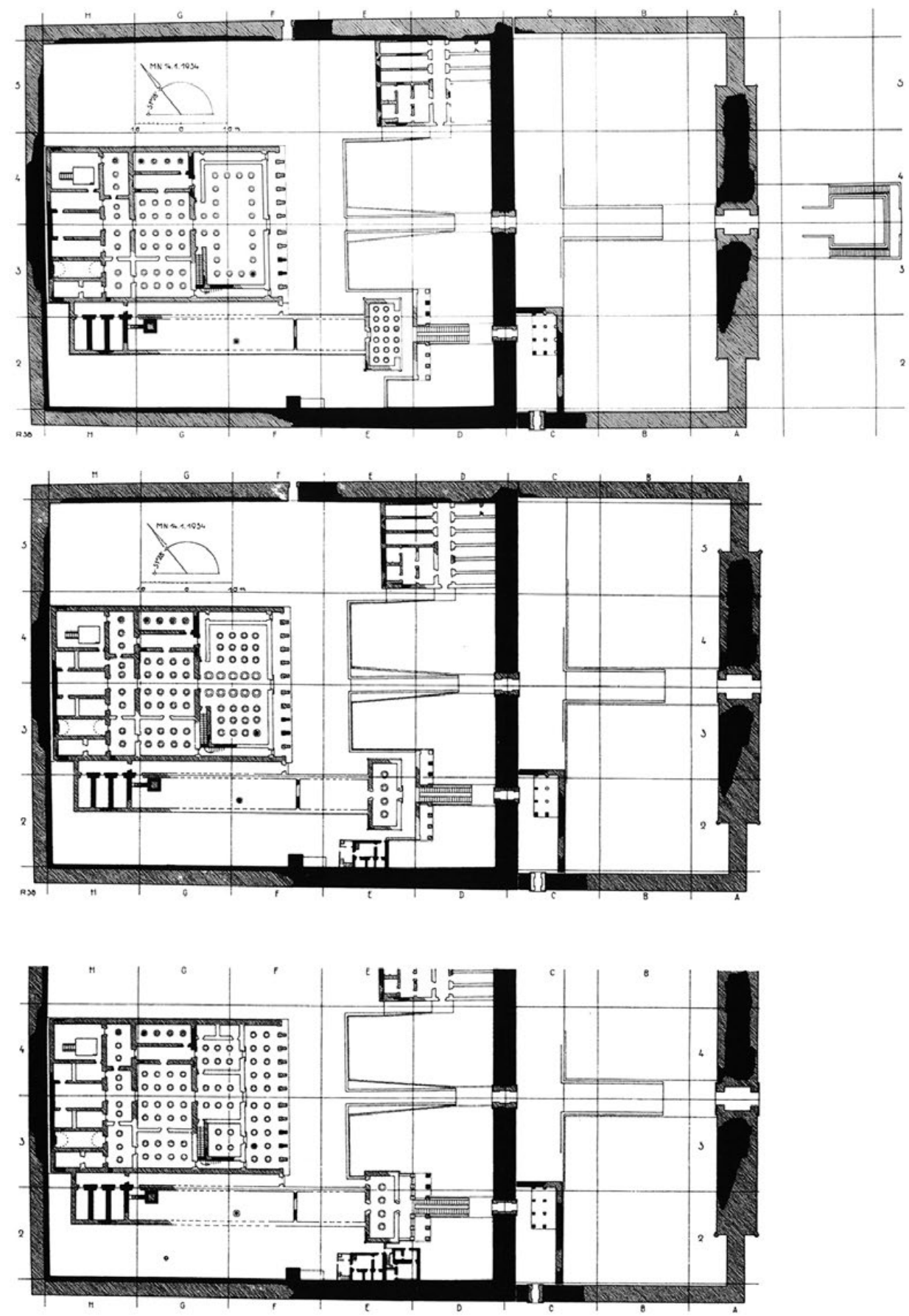

1. Hypothetical reconstructions of the Henket-ankh proposed by Ricke: A (top), B (middle) and C (bottom) (Ricke 1939: Pls 5-7). 
resumed work at the site (1934-1937). He carried out a meticulous chronological and architectural study based on the remains found in situ ${ }^{4}$ and proposed three possible reconstructions (A, B and C; Fig. 1) of the plan of the temple, ${ }^{5}$ suggesting that the complex may have been similar to other constructions of Western Thebes and to the Akh-menu. ${ }^{6}$ The current SpanishEgyptian excavation and restoration project directed by Dr Myriam Seco Álvarez started in 2008. It is succeeding to complete the plan of the temple and to bring to light a large amount of materials, as well as to improve our understanding of this interesting monument.

The ' $h w t M n-h p r-R^{\top}$ Hnkt- $n h$ ' was the Temple of Millions of Years destined to the eternal regeneration on earth and in the netherworld of the royal power. ${ }^{8}$ Its construction probably begun during the coregency of Hatshepsut and Thutmose III. ${ }^{9}$ In fact, some similarities between the Henket-ankh and the temple of the queen at Deir el-Bahari can be easily noted. Unfortunately, not much has remained in situ from the original architecture of the Henket-ankh: some remains of the foundations of the walls, column bases and two pillars, as well as part of the pavement.

This paper focuses on the characteristics and decoration of vertical architectural elements with support functions, that is to say the columns and pillars from this temple. ${ }^{10}$ Since the first kings of the Eighteenth Dynasty imitated the architecture of the early Middle Kingdom, ${ }^{11}$ in the monuments of this date the geometric type predominates, namely squared pillars as well as polygonal, also called protodoric or fluted columns. This is particularly clear in the case of the Temple of Hatshepsut at Deir el-Bahari, referring in style to the neighbouring Temple of Mentuhotep II, which served also as a model for other temples of Western Thebes. ${ }^{12}$ This was also the case of the Henket-ankh.

a report in 1906 and a plan of the temple in 1907. Only a few large fragments of reliefs and other architectural elements were still on the site when excavations in the late nineteenth and early twentieth centuries took place (Seco Álvarez 2009; Seco Álvarez, Radwan 2010; Seco Álvarez et al. 2010).

${ }^{4}$ Ricke 1939: Pl. 4. However, some areas were not excavated, including the north-western corner of the enclosure wall, the west wall, the north-eastern and the southern part of the second court, as well as a large part of the first court and the pylon.

${ }^{5}$ Ricke 1939: 9-15, Pls 5-7.

${ }^{6}$ Laskowski 2006: 209.

${ }^{7}$ For a description of the temple and the works carried out at the site, see, among others: Seco Álvarez, Radwan 2010; Seco Álvarez 2012; 2014; 2015; Seco Álvarez et al. 2012-2013; Seco Álvarez, Martínez Babón 2020.

${ }^{8}$ Bonhême, Forgeau 1988: 296-297; Leblanc 2010: 46-53; Ullmann 2002: 661-670. However, other constructions were given this same denomination during the reign of Thutmose III, including the temple that this king constructed at Deir el-Bahari between the monument of Hatshepsut and that of Mentuhotep II. Nevertheless, his funerary cult was most likely performed in the Henket-ankh (Stadelmann 1979: 304; Dolińska 1994: 33; Haeny 1997: 96, n. 55).

9 Ricke 1939: 16-25, 29; Seco Álvarez 2012: 68.

${ }^{10}$ The study of these elements has been partially dealt within the PhD thesis of the author (Chapon 2018b).

${ }^{11}$ Unfortunately, there are very few preserved sacral complexes from the Middle Kingdom compared to the Old and the New Kingdom. This is mainly due to the fact that New Kingdom kings dismantled most of the building of their direct predecessors (Phillips 2002: 65, 79; Goyon et al. 2004: 18).

${ }_{12}$ From the Sixth Dynasty, the geometric style started to predominate, which evolved into the polygonal style during the Middle Kingdom (Phillips 2002: 65). However, it seems that geometric and polygonal forms decreased in popularity by the end of the Eighteenth Dynasty (Phillips 2002: 97). 


\section{INTRODUCTION TO THE ARCHITECTURE OF THE HENKET-ANKH}

The Temple of Thutmose III was located at the limit of the Theban mountain range (Fig. 2). ${ }^{13}$ As other temples of Western Thebes, this complex was organised on terraces. The desired effect should have been similar, albeit on a smaller scale, to that of the Temple of Hatshepsut at Deir el-Bahari. ${ }^{14}$ From an aesthetic point of view, it had to be very attractive and monumental. ${ }^{15}$ As a typical New Kingdom temple, a central axis divided the monument into two halves ${ }^{16}$ and the rooms were generally arranged symmetrically to the North and to the South of this axis (Figs 1, 3). ${ }^{17}$

Both limestone and sandstone are documented in the Henket-ankh, as it is the case in other structures of Western Thebes. ${ }^{18}$ The state of conservation of the temple certainly makes it difficult to interpret the way in which one or the other type of stone was used. In the Henket-ankh, the only remaining still in situ part of slabs, some fragments of door jambs, among them those corresponding to the door of the pylon, ${ }^{19}$ and wall reliefs, probably belonging to the area of the sanctuary, are made of limestone. Most of the decorated architectural elements were cut out of sandstone. This was indeed particularly the case of the vertical architectural elements with support function. All that remains of pillars and columns in situ, as well as all the scattered fragments of these elements discovered during the excavations on the site, are made of sandstone (Figs 4-5) ${ }^{20}$

${ }_{13}$ Seco Álvarez 2015: 106-107.

${ }_{14}$ See: Wysocki 1986; 1992.

15 Seco Álvarez 2015: 107.

${ }^{16}$ Badawy 1968: 365; Gundlach 2001.

${ }^{17}$ Gabolde, Gabolde 1989.

${ }^{18}$ The occurrence of both limestone and sandstone is often observed in monuments from the times of Thutmose III. See, e.g. the small temple of the Eighteenth Dynasty at Medinet Habu, the constructions of Thutmose III at Karnak and his temple at Deir el-Bahari (Harrell 2016: 1). In the case of the Henket-ankh, and contrary to the Temple of Thutmose III at Deir el-Bahari, at first glance it seems that limestone and sandstone were not applied in the same wall. This distribution could be due to a symbolic reason, since limestone was apparently often considered more 'noble' than sandstone. However, in the case of the Henket-ankh a chronological explanation for this phenomenon can also be proposed. As the first phase of construction of the temple was probably carried out during the coregency of Thutmose III and Hatshepsut (Ricke 1939: 16-25, 29; Seco Álvarez 2012: 68), it is possible that at that time local limestone from Qurna was applied, the same as identified in the Temple of Hatshepsut and the Temple of Thutmose III at Deir el-Bahari. Other type of limestone attested in the Henket-ankh, that probably was used in the oldest parts of the temple have been also identified in the Temple of Thutmose I at Qurna and Thutmose III at Deir el-Bahari. Nonetheless, most of the Henket-ankh was built of sandstone, and it is hard to establish whether this material was used when Hatshepsut was still alive or after her disappearance. Some architectural elements, such as roofs, columns and pillars were probably planned from the beginning as made of sandstone.

19 Seco Álvarez 2015: 112.

${ }^{20}$ While at the beginning of the Eighteenth Dynasty in the Theban area limestone is still the most commonly used kind of stone, it is gradually replaced by sandstone for construction of the major temples (Harrell 2012; 2016; Harrell, Storemyr 2009). This could be due to the fact that sandstone was much more resistant and flexible, and architectural elements from this material could have been used to construct longer architraves and, therefore, bigger temples. In the Temple of Thutmose I in Qurna and Thutmose III at Deir el-Bahari, all architectural elements were with no exception made of sandstone. In the Temple of Thutmose III at Deir el-Bahari, some door lintels were also made of granite but never in limestone. Another reason for preference for this material could have been that closer and bigger veins of sandstone were available at Gebel el-Silsileh as well as because of sandstone water resistance (De Putter, Karlshausen 1997; 2003). 
The Decoration of the Columns and Pillars from the Henket-ankH ...

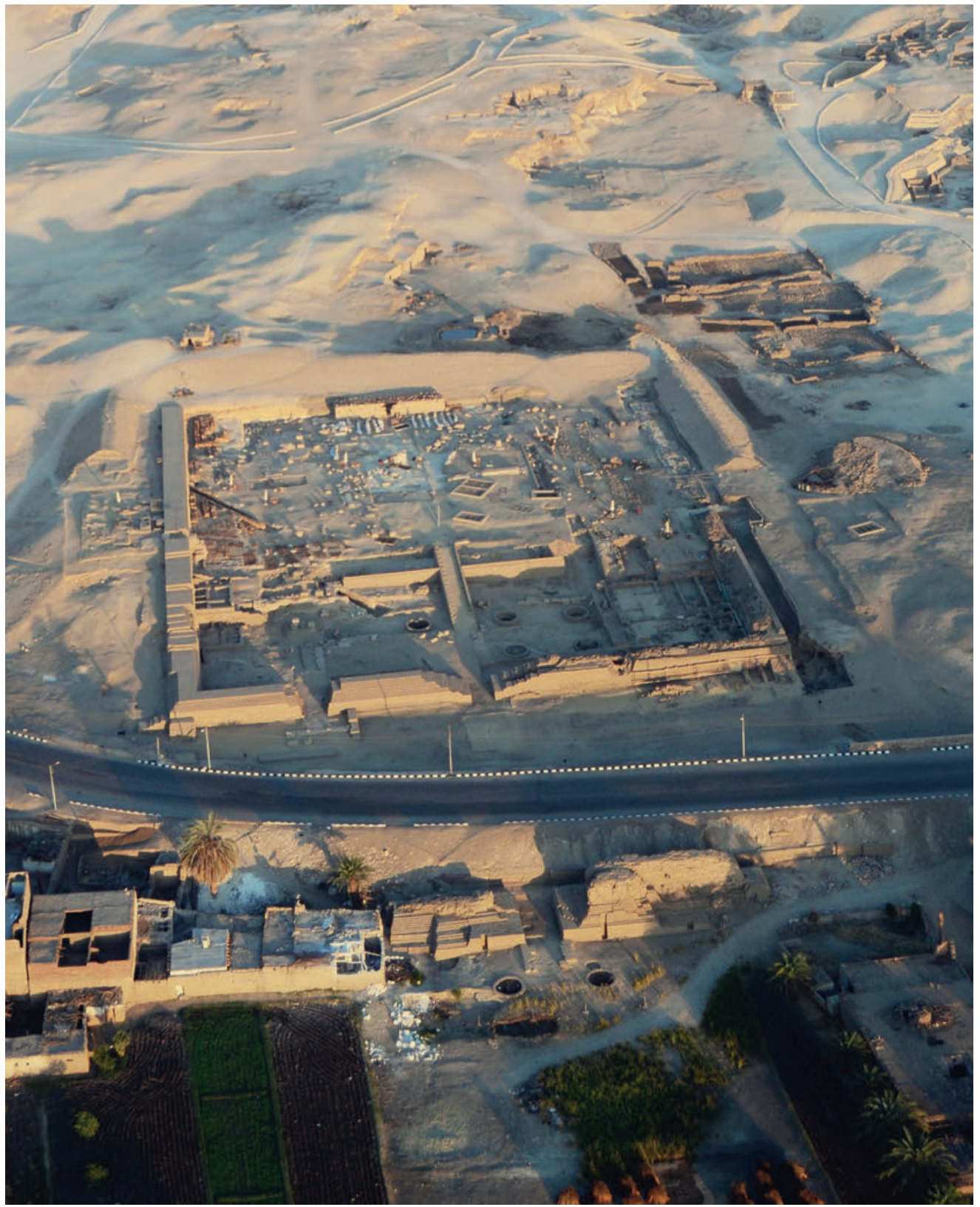

2. View of the temple from the East (Phot. L. Chapon (C) Thutmosis III Temple Project). 


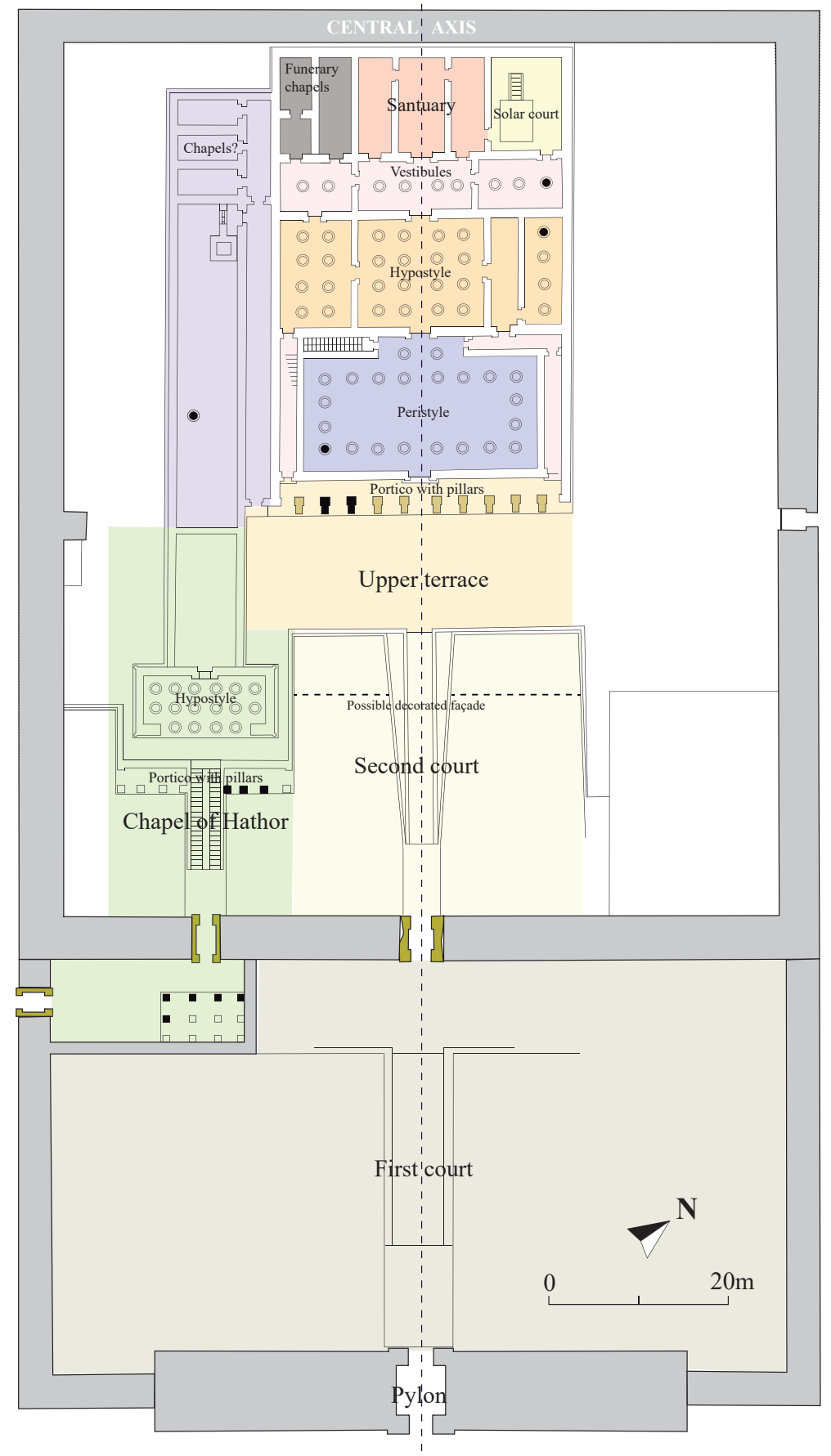

3. General plan of the temple based on Ricke's reconstruction A; elements being in situ are marked in black (Drawing: L. Chapon (C Thutmosis III Temple Project; based on: Ricke 1939: Pl. 5). 

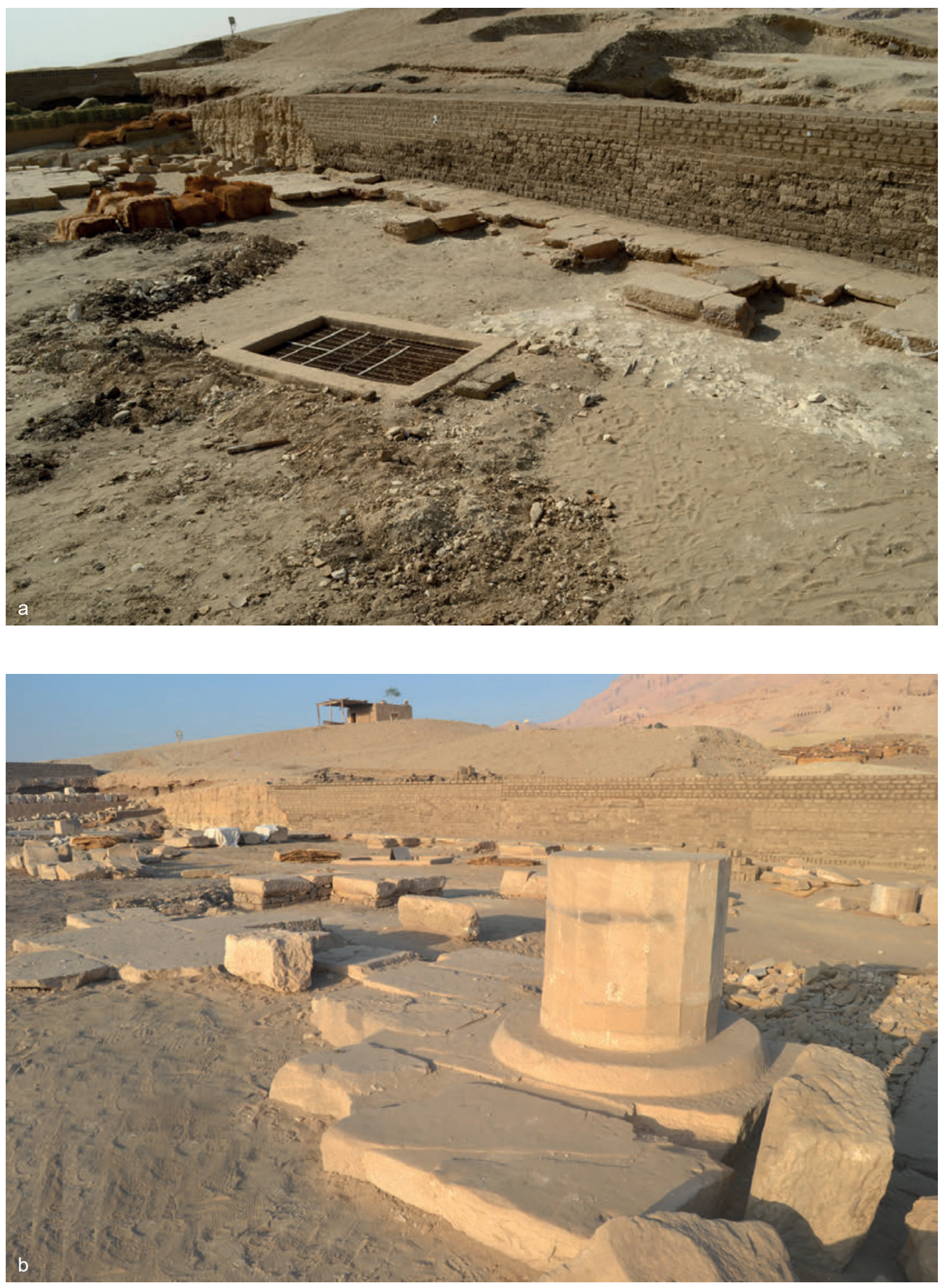

4. The sandstone architectural elements that are still in situ in the temple: a. sanctuary area; b. column fragments in the hypostyle area (Phot. L. Chapon $(\mathcal{C}$ Thutmosis III Temple Project). 

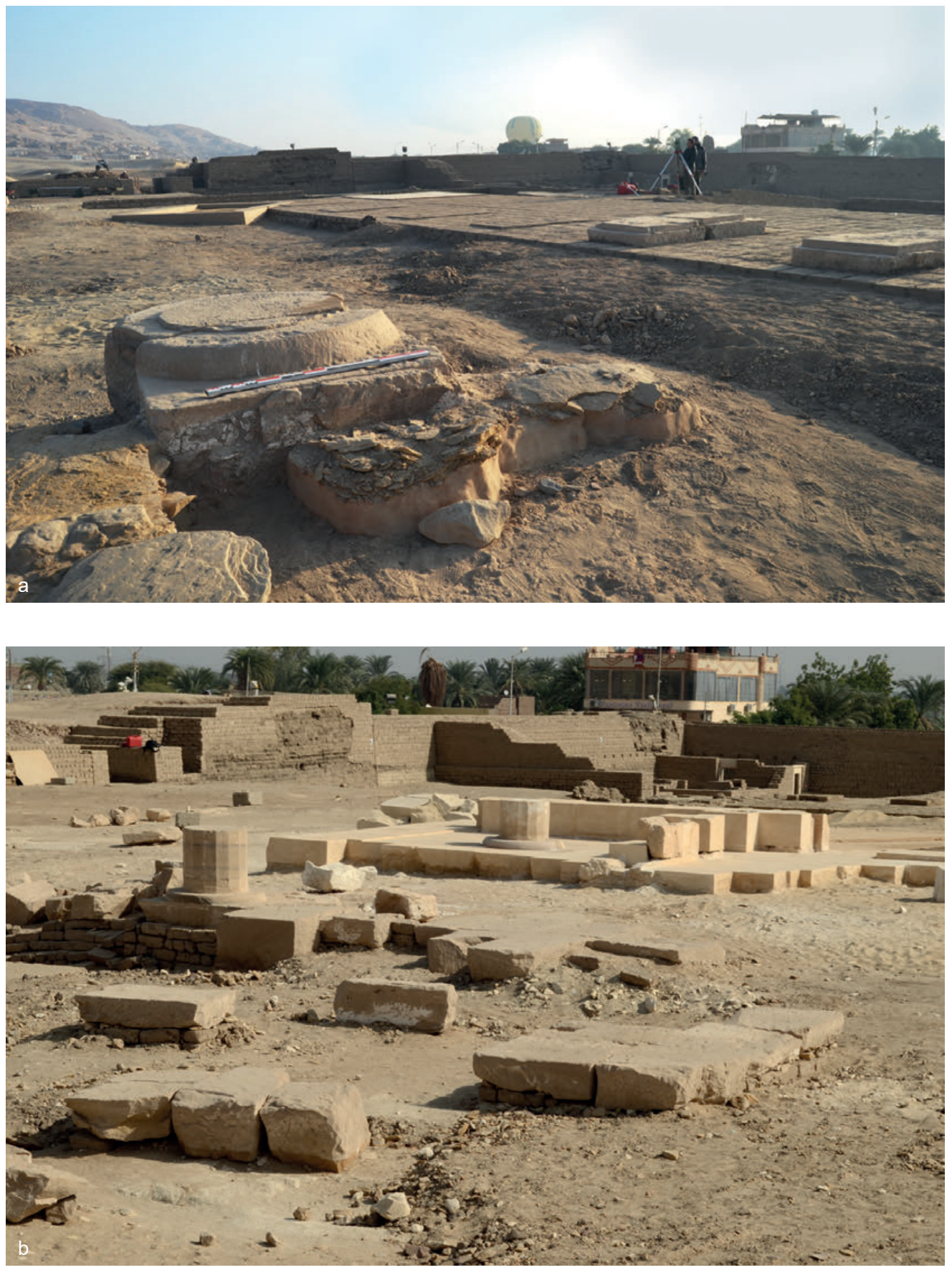

5. The sandstone architectural elements that are still in situ in the temple: a. column base in the south-eastern corner of the peristyle and bases of pillars in the southern end of the portico; b. hypostyle area from the South-East (Phot. L. Chapon (C) Thutmosis III Temple Project). 
For what is known so far, among the parts of the temple constructed in stone one should enumerate the main temple in the upper terrace and the portico, as well as a chapel devoted to Hathor, located to the South. ${ }^{21}$ The similar pattern of stone usage can be observed in the Temple of Hatshepsut at Deir el-Bahari. ${ }^{22}$

In listed above parts of the Henket-ankh some evidence of vertical architectural elements with support function was recorded. Ricke proposed to place in front of the sanctuary area, a series of three elongated vestibules with a row of columns (Figs 1, 3, 4a). The base of one of the three columns of the northern vestibule is preserved in situ (Figs $\mathbf{4 b}, \mathbf{5 b}){ }^{23}$ The hypostyle could have had sixteen columns. To the south, a single room with eight columns was proposed, while the last room to the north would have had four columns, of which the base of the western most is still in situ (Figs 1, 3). ${ }^{24}$ In front of hypostyle, Ricke reconstruct a large peristyle court with a row of columns on each side (Fig. 1, reconstruction A). The only preserved in situ base is to be found in the south-eastern corner of the court (Fig. 5a). According to one of the reconstruction proposed by Ricke, in this area, on the main axis of the temple and peristyle, two rows of larger columns could have been also located, and some other, smaller to the south and north, occupying all the court space (Fig. 1, reconstruction B and Fig. 3). ${ }^{25}$ Two rows of larger columns would suggest that the roof in the central part of this area was higher, and there were also some windows, as it was the case of the Temple of Thutmose III at Deir el-Bahari. The base of columns identified in situ shows the typical circular chiselled mark to indicate the placement of the first drum. Many other sandstone blocks discovered in the upper terrace were also part of the base of columns. Finally, a porticoed façade in the upper terrace consisted of a row of ten pillars, two bases of which are still in situ on the southern side (Figs 1, 3, 6). ${ }^{26}$ These should have been Osiride pillars, like in the Temple of Hatshepsut at Deir el-Bahari, the Temple of Amenhotep II or that of Thutmose IV located in Western Thebes. The two bases show clearly the square area prepared for the pillar and, in front of it, a section to place the Osiride statue. ${ }^{27}$ In fact, Weigall ${ }^{28}$ declared in his report that he had discovered a fragment of the crown from this kind of statues. ${ }^{29}$ The distance between the pillars and one of the still preserved in situ base of columns from the peristyle court, does not allow reconstruction here of two rows of pillars. According to Ricke, either the portico consisted

${ }^{21}$ Seco Álvarez 2015: 106.

${ }^{22}$ Dąbrowski 1968: 39-46.

${ }^{23}$ Ricke 1939: 12.

${ }^{24}$ Ricke 1939: 13, Pls 5-6.

${ }^{25}$ Ricke 1939: 14, Pl. 6.

${ }_{26}$ Ricke 1939: 13-14; Seco Álvarez 2015: 113-116.

${ }_{27}$ This type of pillar is never found in the internal parts of buildings but always in a court, façade or portico (Cénival 1964; Czellár 1981; Leblanc 1980). The first example of this type of pillars dates back to the Middle Kingdom (Czellár 1981; Leblanc 1980). In the New Kingdom, they became a common element in temples (Leblanc 1980). They are no longer attested in later periods (Czellár 1981).

${ }^{28}$ Weigall 1906: 123-125.

${ }_{29}$ The study of fragments that could correspond to Osiride statues is still to be finished. The very fragmentary state of the material undoubtedly makes this task very difficult. 

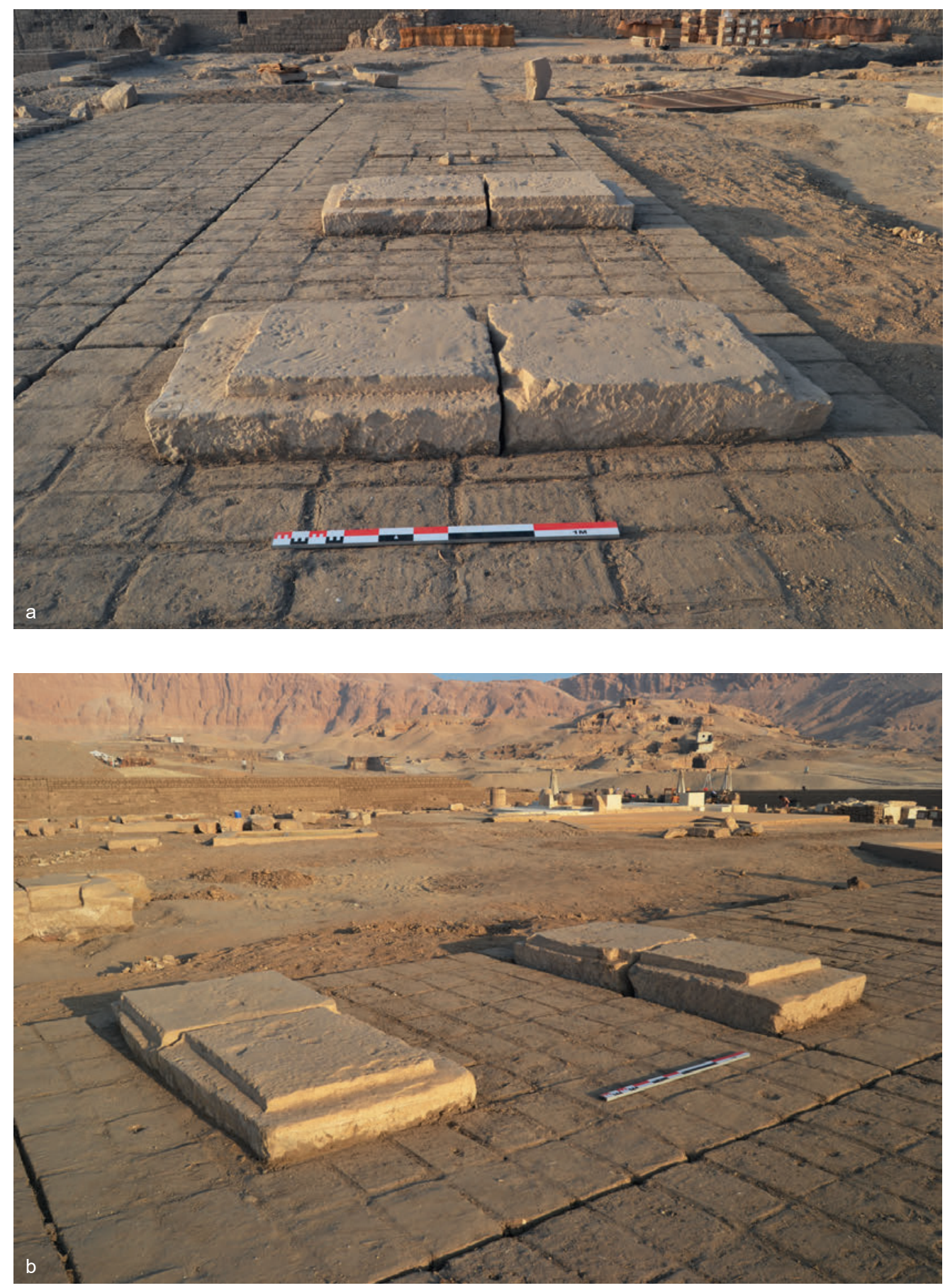

6. Bases of pillars that are still in situ in the portico area: a. view from the North; b. view from the South-East (Phot. L. Chapon ( Thutmosis III Temple Project). 


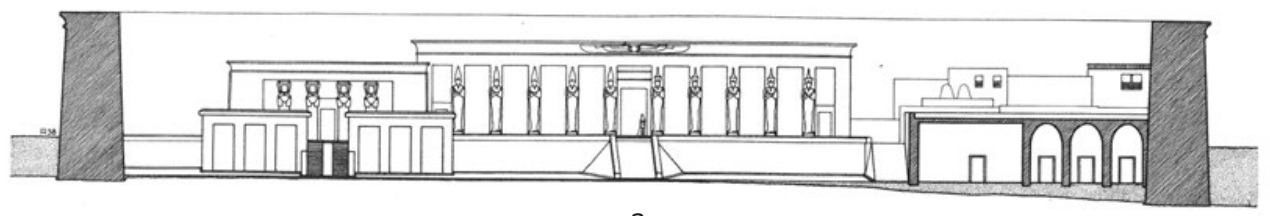

a
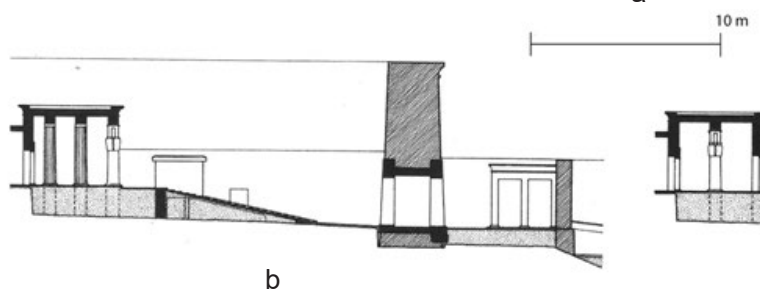

b
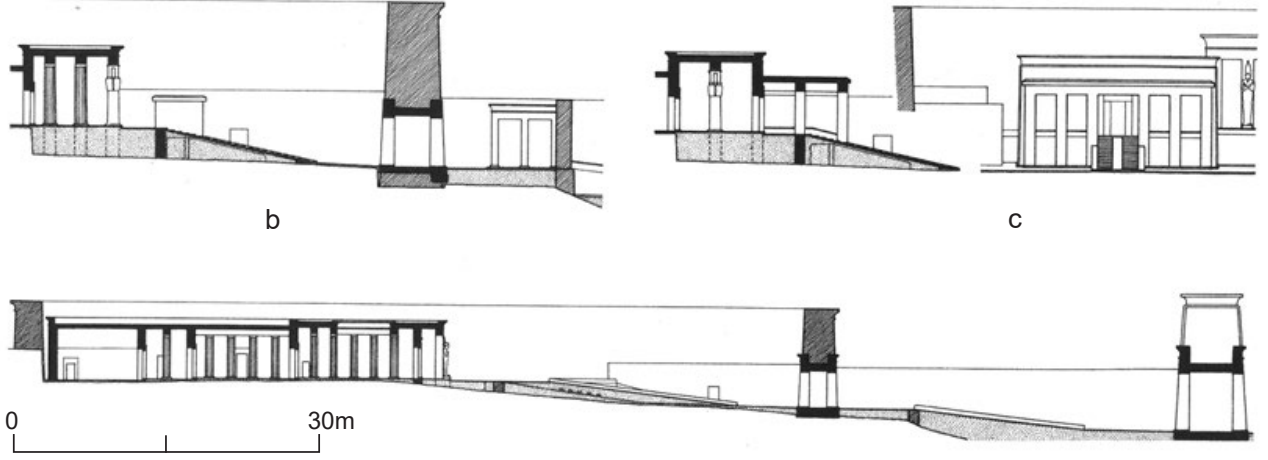

d

7. Reconstitution of the façade of the temple and sections through the complex as proposed by Ricke: a. front view of the façade according to reconstruction A; b. section through southern part of the Hathor chapel according to reconstruction A; c. section and front view of the Hathor chapel according to reconstruction $\mathrm{C}$; d. section through the temple according to reconstruction A (Ricke 1939: P1. 7).

of a single row of ten Osirian pillars (Fig. 1, reconstruction A and B), or of a row of pillars followed by two rows of columns (Fig. 1, reconstruction C). ${ }^{30}$ Five pillars were placed on each, southern and northern side of the portico. A row of stone blocks located on the northern side of the ramp leading to the upper terrace, and corresponding elongated cut in the bedrock on the southern side,$^{31}$ were recently identified. So far, there is no evidence to suggest that in this area pillars or internal rooms were located. Therefore, a decorated façade could have existed on each side of the ramp (Fig. 3).

It is highly probable that a chapel dedicated to the goddess Hathor was built in the southern area of the main temple, as it is the case of the Temple of Hatshepsut at Deir el-Bahari. ${ }^{32}$ Analysis of the architectural rearrangement shows that this sanctuary was added at a later date, its decoration being probably finished during the reign of Amenhotep II, and not a part of the complex in its original form. ${ }^{33}$ A ramp parallel to the main one (Figs 1, 3, 7-8) led to the terrace on which the chapel stood. A portico supported by pillars composed the

${ }^{30}$ This paper gives preference to reconstruction A and B of Ricke (Ricke 1939: Pls 5-7) that includes a single row of pillars in the portico. The reconstruction A is the one followed on Fig. 3.

31 Seco Álvarez, Martínez Babón 2020: 187-188.

32 Haeny 1997; Myśliwiec 1985: 6; Beaux 1995; 2012; Beaux, Grimal, Polin 2012; Beaux et al. 2012; 2016; Bernhauer 2005: 46-52; Karkowski 2001.

33 Ricke 1939: 21. 


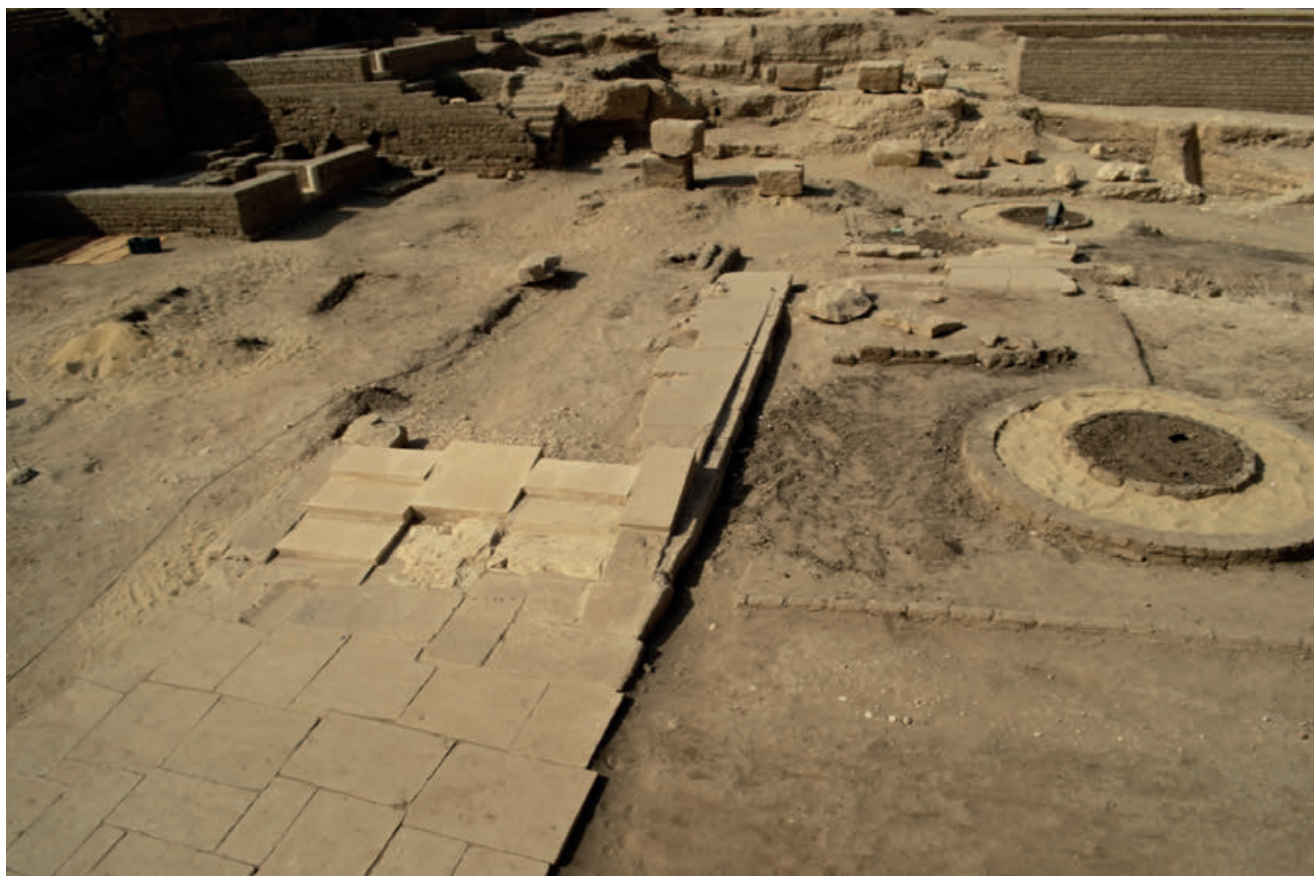

8. Ramp leading to the Chapel of Hathor; view from the East (Phot. L. Chapon (C) Thutmosis III Temple Project).

main façade and gave access to a hypostyle and a sanctuary. ${ }^{34}$ Three bases of pillars have been identified in situ on the northern side of the ramp, and none of them is Osiride. Ricke ${ }^{35}$ proposed three possible reconstructions for this area. According to them, the ramp could have been bordered on each side either by four (Fig. 1, reconstructions A-B) or by three pillars (Fig. 1, reconstruction C). In the last case, a second row of higher pillars, could have existed at the upper level of the ramp, serving as a portico and access to the hypostyle hall. In such a case, the first row of pillars would have partially limited view towards the façade of the hypostyle hall (Figs 1, 3, 7) ${ }^{36}$ No columns from the hypostyle hall have been identified in their original position, as this area was heavily damaged. A series of pillars, but much smaller, probably also existed in the entrance hall to the chapel, located in the area of the first court. Two bases of these pillars are still in situ (Figs 1, 3). ${ }^{37}$ The current state of preservation of the architecture and decoration of the temple makes it difficult to further interpret the area of the Chapel of Hathor. No architectural remains discovered in the temple could be so far unequivocally attributed to this chapel.

\footnotetext{
34 Ricke 1939: 21-25; Seco Álvarez 2015: 106.

35 Ricke 1939: 22-23.

36 Ricke 1939: 21-23, reconstruction C, Pls 6-7.

37 Ricke 1939: 24-25.
} 


\section{FRAGMENTS OF POLYGONAL COLUMNS}

The major part of columns discovered in the temple seems to correspond to polygonal /protodoric columns with sixteen sides. Those columns which were found in their original position have not preserved inscription. From most of the columns remain only few blocks and some scattered fragments, and a large part of them are anepigraphic. They show slightly fluted surfaces (Fig. 4b). Many fragments preserve a surface covered with plaster and a light-yellow colour. This probably aimed at imitating limestone, as in other temples, e.g. of Mentuhotep II at Deir el-Bahari. ${ }^{38}$ Most fragments with inscription are very small and they only preserve part of two or three original faces. The sole exception is a large block (see below, inv. no. 4, Fig. 11), with a single vertical column of inscription. Although it is not possible to affirm that all of the columns were inscribed in a similar manner, this seems most likely. All inscriptions are in sunk relief and not delimited by a vertical line. The preserved fragments do not make it possible to reconstruct entire columns or to suggest their original position in the temple. The inscriptions have different orientations, some of them were painted blue while others yellow. Although the inscriptions are scarce, we can get some general impression about their character and the nature of these texts. However, not all the inscriptions were arranged in the same way, as it is the case, for example, at the $A k h-m e n u .{ }^{39}$

The analogies from other temples allow one to suggest that the upper part of the vertical inscriptions on all the columns included the Horus and the Sun Disc and an uraeus supporting an $a n k h$-sign. This composition corresponded to the title of the Horus name (e.g. inv. no. 1640, Fig. 9) followed by the name of Thutmose III ' $K 3-n h t-h{ }^{\top}-m-W 3 s t$ ' included in the serekh or the façade of palace motif (inv. no. 14796, Fig. 9). The serekh is preserved, for example, on inv. no. 1292 (Fig. 9). A pet-sign undoubtedly surmounted the decoration of the columns.

No fragment documents the presence of the Nebty name or the Golden Horus under the Horus name. This does not mean that they did not existed, since the state of conservation of the material is very bad. Certain royal epithets other than those accompanying the cartouches are, on the contrary, to be noted: ' $n \underline{t} r$ [nfr]' after the serekh (inv. no. 1292, Fig. 9), probably the epithet ' $h k$ ' 'Iwnw' (inv. no. 14828, Fig. 9; inv. no. 2698, Fig. 10). This epithet may refer to Amun, Atum or the king. ${ }^{40}$ However, no sign of damnatio is apparent, which would indicate that it was rather an expression accompanying the royal titulature. ${ }^{41}$

${ }^{38}$ Phillips 2002: 291.

${ }^{39}$ Pecoil et al. 2000: Pls 1, 12-16.

${ }^{40}$ See, for example: Naville 1906: Pl. CXX.

${ }^{41}$ This epithet is included in the cartouche of the birth name of Thutmose III, but also outside of the cartouches (Urk. IV: 551) following the Horus name of the king in, for example, horizontal inscriptions. This is the case of a large horizontal inscription surmounting the text of the 'Annals' (Gabolde, Gabolde 2015: 78) and in a scene from the Temple of Ptah in Karnak. The epithet could be completed as ' $n \underline{t} r$ h $h$ J 'Iwnw' what has been translated as 'the god lord of Heliopolis' (Gabolde, Gabolde 2015: 78) or as 'the god who rules in Heliopolis' (Epigraphic Survey 2009: 19, Pl. 11b). On two upper door jambs of the Temple of Ptah, there are the expressions ' $n t r$ nfr hkJ Jwnw'. The original decoration of one of the doors dates to the reign of Thutmose III 


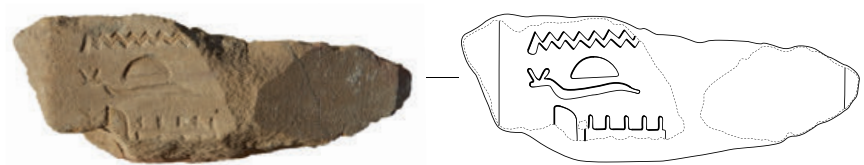

inv. no. 14670

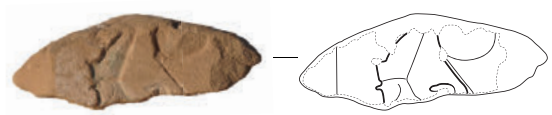

inv. no. 1640

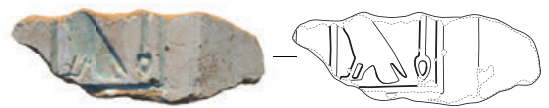

inv. no. 14796
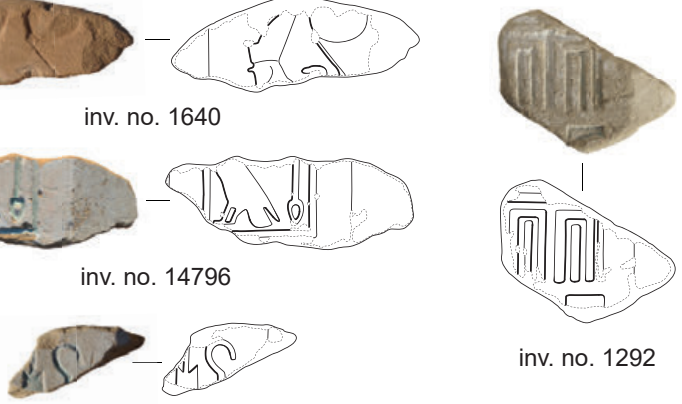

inv. no. 1292

inv. no. 14828

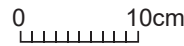

9. Fragments of polygonal columns with inscriptions painted blue (Phot. and drawing: L. Chapon $\mathbb{C}$ Thutmosis III Temple Project).

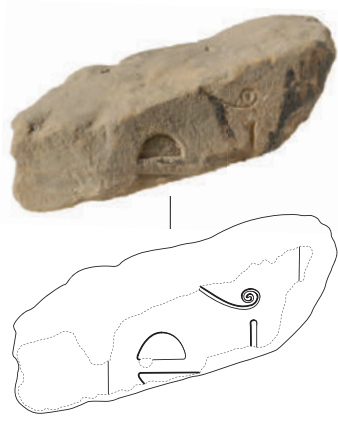

inv. no. 460

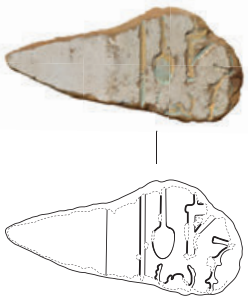

inv. no. 14375

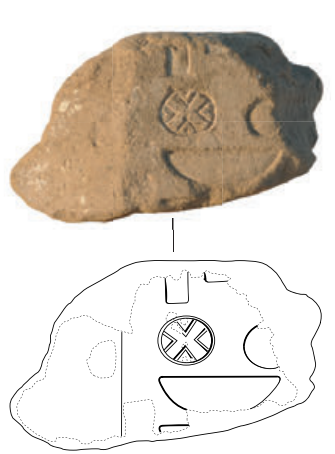

inv. no. 2698

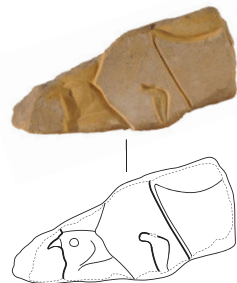

inv. no. 125

0 10 $10 \mathrm{~cm}$

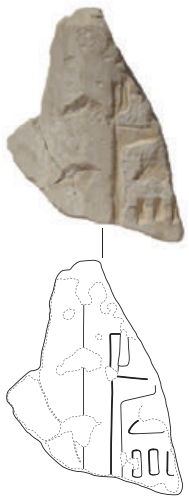

inv. no. 1261

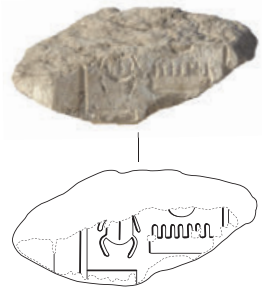

inv. no. 1903

10. Fragments of polygonal columns with inscriptions painted yellow (Phot. and drawing: L. Chapon $\mathbb{C}$ Thutmosis III Temple Project). 
All the cartouches preserved on columns fragments from the Henket-ankh seem to belong to Thutmose III. The throne name is not accompanied by any epithet, while ' $n f r$ hpr', ' $n f r$ $h p r w$ ' and ' $h k 3 M^{\top}{ }^{`} t$ ' follow the birth name. The first two of them were common during the whole reign of Thutmose III and continued to be used with other epithets following the disappearance of Hatshepsut. ${ }^{42}$ The last one, ' $h k 3{ }^{3} M{ }^{\top} t$ ' is used during the sole reign of Thutmose III, that is from regnal year $21 / 22$. This is also the date of the first campaign of major constructive works after the disappearance of the queen. ${ }^{43}$ Although, this epithet is attested on monuments from the times of Hatshepsut, in all the cases it seems to be a recarving of the original epithet ' $n f r$ hpr' that probably occurred in a period after the end of Thutmose III' reign, maybe during the Amarna period. ${ }^{44}$ One column's fragment from the Henket-ankh documents such a change of the epithets (inv. no. 1091).

The above-mentioned best-preserved block (inv. no. 4, Figs 11-12), which retains the majority of the original sides shows that at least some columns presented the two cartouches in the same inscription, ${ }^{45}$ and the throne name precedes that of birth. Weigall, who already published this inscription, suggested that it comes from a sector that corresponds probably to the hypostyle hall. It is possible to reconstruct the inscription as ' $[\ldots]$ nswt bjtj $M n-h p r-R^{\odot} z 3 t R^{\top} n$ [ht.f $\underline{D} h w t y-m s$ (epithet?)]'. ${ }^{46}$ Its arrangement is similar to the inscriptions on the thirty-two sided columns of the Temple of Thutmose III at Deir el-Bahari. ${ }^{47}$ This fragment does not preserve any polychromy.

Hammering marks can be seen around and inside the cartouche on this block and this side is more concave than the other of the column. Furthermore, a feminine ending of the title accompanying the birth name (' $z 3 t R^{{ }^{\prime}}$ ), follows the throne name. All this evidence could suggest that it was originally the name of Hatshepsut given here. Her cartouches have been documented on two sandstone fragments. These are two cases when her inscriptions were not erased. ${ }^{48}$

Other expressions, such as 'mry Jmn', 'beloved by Amun', follow the cartouches. The lower part of the inscriptions on columns included the names and epithets of a divinity. Those preserving the name of Amun present evidence of damnatio and restoration. His name could have been accompanied by several epithets, two of which have been preserved: 'nswt ntrw' (inv. no. 1261, Fig. 10) and ' $n b$ nswt $t 3 w j$ '. In some cases in the lowermost

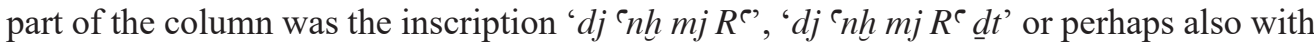

(Biston-Moulin, Thiers 2016: 252-253 (vol. I); 176 (vol. II)), while the second was modified by Takelot II (Biston-Moulin, Thiers 2016: xviii, 156-157 (vol. I); 105 (vol. II)).

42 Von Beckerath 1999: E6 ${ }^{\circ}$, E7, 138-139.

${ }^{43}$ Von Beckerath 1999: 139; Biston-Moulin 2012b.

${ }^{44}$ Biston-Moulin 2012a.

45 Weigall 1906: 140, Transcription Q.

${ }^{46}$ Weigall does not seem to acknowledge the feminine ending ' $t$ ' nor the sign ' $n$ ' at the bottom.

${ }^{47}$ Niedziółka 1998.

${ }^{48}$ Chapon 2018b: 129-130. Her name appears together with the cartouche of Thutmose I also on mudbricks used in the enclosure wall of the temple (Weigall 1906: 129; Ricke 1939: 8, 36, no. 15). It is likely that these stamped bricks were a surplus of material originally meant for the Temple of Thutmose I and posteriorly used in the Henket-ankh (Iwaszczuk 2016: 203). 

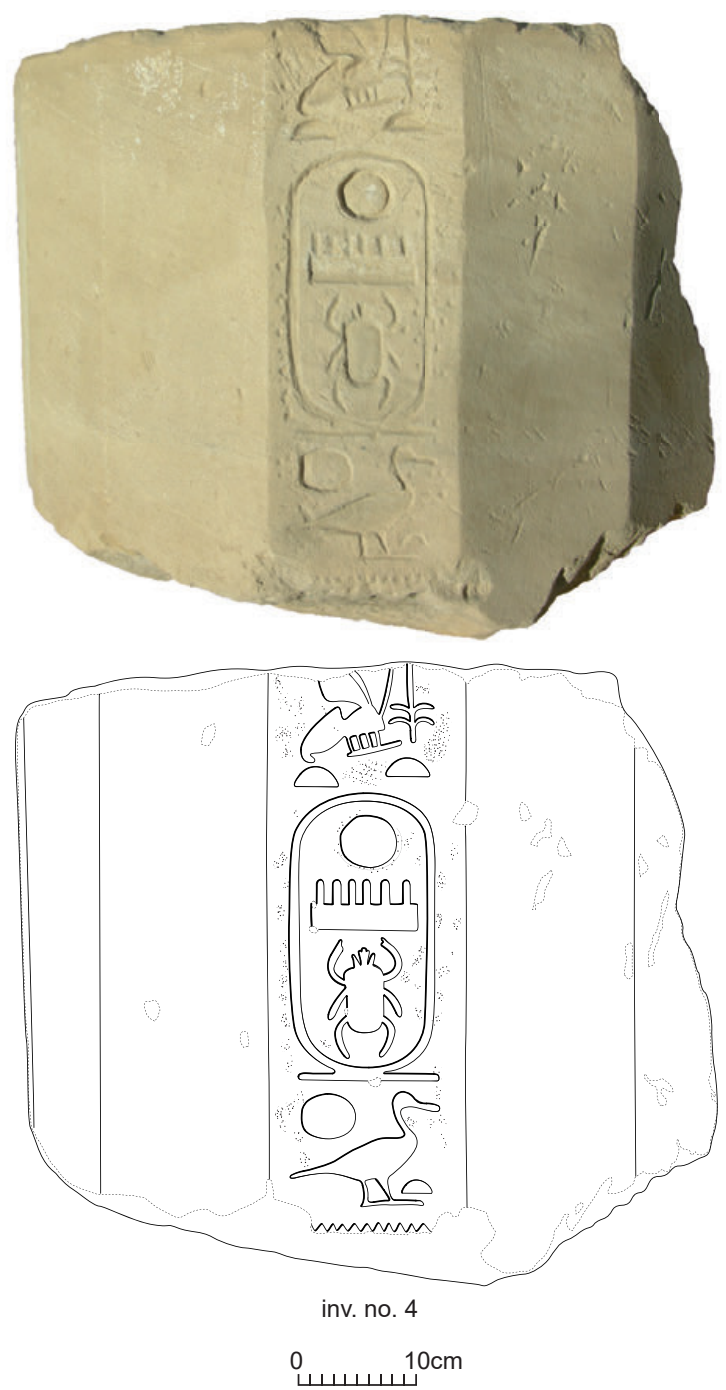

11. Large fragment of polygonal column; no polychromy preserved (Phot. and drawing: L. Chapon (C) Thutmosis III Temple Project).

'dj ' $n h \underline{d} \underline{d}$ ', similar as at the Akh-menu. The expression ' $j r . n . f m m n w . f n j t(j) . f J m n-R$ ', 'He made [it] as his monument for his father Amun-Re' must have been carved at least on some columns. An example is inv. no. 14670 (Fig. 9), without traces of polychromy. Since the name of the temple is also preserved on a column fragment (inv. no. 1903, Fig. 10), it is possible to suggest that the discussed inscriptions included also kings dedication of the temple to Amun-Re, the main god of the temenos.

The material attests also an epithet consisting from the word ' $t j t$ ' probably followed by ' $n b$ t3wj' (inv. no. 460, Fig. 10). Two options are possible with regard to the divinity 
which preceded this title. ${ }^{49}$ Both ' $t j t$ Jmn' and ' $t j t R^{e '}$ are attested during the reign of Thutmose III, but were not included inside his cartouche. ${ }^{50}$

Finally, a fragment seems to include the name of the god Montu (inv. no. 3401). In the Temple of Thutmose III at Deir el-Bahari, a fragment of a thirty-two sided column retains the inscription ' $z 3 M n t w$ ', where the king is said to have been designated as the son of a divinity followed by an expression including the name of Montu, perhaps 'beloved of Montu' ${ }^{51}$ The name of Montu - similar as in case of Amun - was erased and later restored.

The classification of the material according to the colour of the inscription gives scarce results since the number of the fragments is too low. In one case (inv. no. 14375, Fig. 10), an original blue polychrome was covered by yellow. The reason behind the choice of the colour is hard to determine. It is possible that, from the beginning, some inscription on the columns had received a yellow polychromy and the other a blue one. However, inv. no. 14375 suggests that a change from blue to yellow should also be taken into account, although this is the only evidence of such a practice.

Blue inscriptions in sunk relief are rare in temple architectural contexts. Granite doors may be painted blue, as in the Temple of Hatshepsut and Thutmose III at Deir el-Bahari. Some fragments that belonged to a scene painted with blue colour, possibly from a small room or niche, are known from the temple of Kumna. ${ }^{52}$ Fragments of octagonal columns ${ }^{53}$ with inscription in blue colour have been found in the Temple of Mentuhotep II at Deir el-Bahari. ${ }^{54}$ Two joined fragments are today in the Metropolitan Museum of New York. ${ }^{55}$ The fragments correspond to the front side of the upper part of a column and it preserves the beginning of the Horus name of the king. ${ }^{56}$ The adjoining sides are also undecorated. A further fragment is today in the Museum of Fine Arts of Boston. ${ }^{57}$ It is inscribed with the cartouche including the birth name of Mentuhotep II. Fragment of corner of columns

49 Also, on a column from the Akh-menu, the name of the divinity is not preserved (Pecoil et al. 2000: Pl. 12).

50 Urk. IV: 552, 19-22.

51 Niedziółka 1998.

52 These fragments, dated from the reign of Hatshepsut/Thutmose III, were dismantled and reused as foundations: fragments 82 and 83 in Caminos 1998: 89-91, Pl. 74; see two joined blocks now in the Museum of Fine Arts Boston (Museum of Fine Art Boston: accession number 25.1510a-b).

53 The simplest form of polygonal or protodoric columns.

54 The fragments were discovered by Edouard Naville on behalf of the Egypt Exploration Fund in the Temple of Mentuhotep II at Thebes and acquired by the Metropolitan Museum in 1907. This temple included pillars and octagonal columns. The columns were of three different sizes, and each of them, was applied in different part of the temple, decreasing in height from East to West: the ambulatory, the middle court, and the hypostyle hall. The discussed fragments with blue inscriptions could be assigned to the ambulatory, according to the width of the front panel. One may assume that the decorated sides of all columns of the ambulatory were facing east, towards the entrance (Arnold 1974: 26, 33, 39, Pls 10, 12b, 15c-d, 16a, 18, 28, 31, 33; 1979: 33, 36-37). See also: Naville, Hall, Ayrton 1907: 27-28, 34; Naville, Clarke 1910: Pls III-V.

55 Hayes 1953: 157; MetMuseum: accession number: 07.230.5a, b.

56 The inscription is $20.8 \mathrm{~cm}$ wide (including the was-sceptre); the inscribed face was $c .24 .1 \mathrm{~cm}$ wide. The inscribed surfaces are wider than those of the Henket-ankh, since these are fragments of octagonal columns and not sixteen sides columns.

${ }^{57}$ Museum of Fine Art Boston: accession number 07.535. 


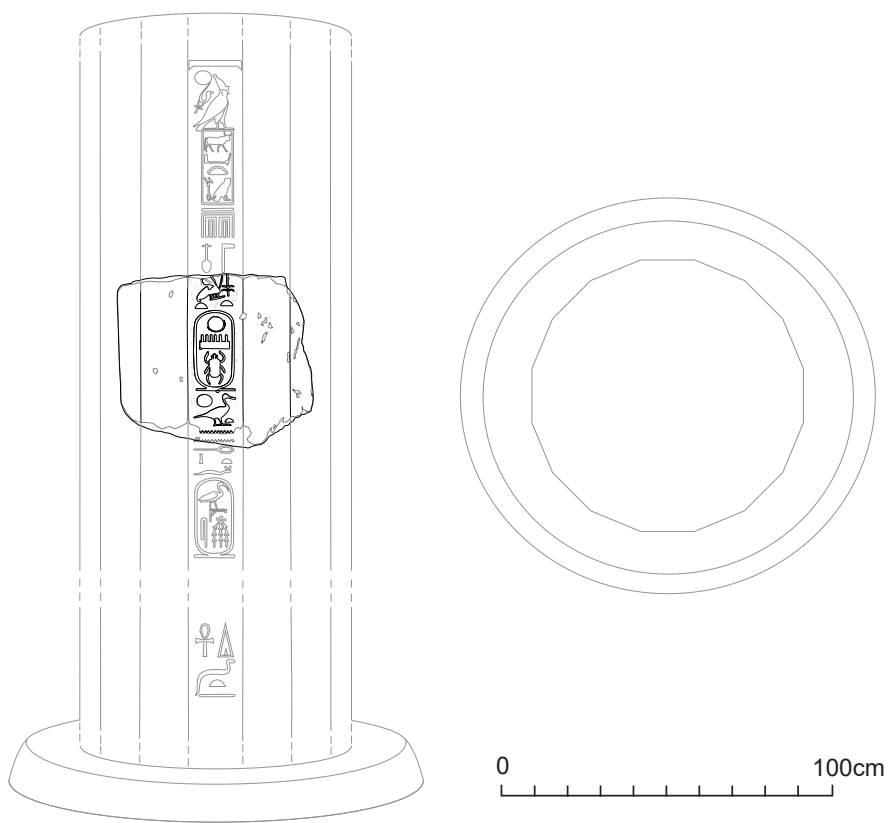

12. Reconstruction of part of the inscription from column based on inv. no. 4 (Drawing: L. Chapon (C) Thutmosis III Temple Project).

covered with a blue colour have also been discovered in another construction at Gebelein, dated to the reign of this pharaoh. ${ }^{58}$

The diameter of the shaft of the columns from the Henket-ankh is approximately $92-93 \mathrm{~cm}$ at the base. All faces of the columns present a fairly regular width, including inscribed ones: approximately $16-17 \mathrm{~cm}$. However, the fragments with a blue inscription have a decorated side a bit narrower than those with a yellow polychromy. Though, as most fragments with blue colour belong to the top of the inscription, it is also possible that the columns taper slightly upwards. The in situ preserved fragments of columns allow to state that the decoration had to start at least $90 \mathrm{~cm}$ above the base level of the column. It was impossible so far to determine the original height of the columns or reconstruct the height of their decorated part. A reconstruction of part of the decoration can be only given for the best preserved block inv. no. 4 (Fig. 12).

Columns of the same type are well attested in other temples of this time ${ }^{59}$ Nonetheless, it is hard to reconstruct arrangement of these columns in the Henket-ankh. Possibly the

${ }^{58}$ Currently in the Egyptian Museum of Turin: CGT 7003/8, CGT 7003/9 (Marochetti 2010: 35, Pls II, LI).

${ }^{59}$ In the Temple of Hatshepsut, only the columns which surrounded the upper court had one of their sides decorated in sunk relief. The yellow painted inscriptions were located on faces wider $(c .38 \mathrm{~cm})$ than the undecorated ones (Wysocki 1980). The lower part of the decoration of columns in the Temple of Hatshepsut consisted of fertility figures or rekhty, but they are not attested on fragments from the Henket-ankh. No fragment 
columns of the two central rows of the peristyle and the hypostyle hall were decorated. The decorated sides could have been oriented towards the main east-west axis. Therefore, the columns with inscriptions facing right would have been placed on the southern side and those oriented to the left, on the northern side. In the case of small rooms and halls, it is even harder to made such a reconstruction and it is also possible that columns located there were undecorated. It is also impossible at the moment to determine whether columns of different colour and different size were differently distributed within the temple.

\section{FRAGMENTS OF HATHORIC CAPITALS AND CIRCULAR COLUMNS}

The oldest preserved building showing Hathoric capitals in situ is the Chapel of Hathor in the Temple of Hatshepsut at Deir el-Bahari. ${ }^{60}$ In geographical terms, this is also the closest parallel to the Chapel of Hathor in the Henket-ankh. ${ }^{61}$ Further analogies from this period are known, ${ }^{62}$ for example, from the Satet temple at Elephantine, ${ }^{63}$ Bubastis, ${ }^{64}$ Serabit el-Khadim ${ }^{65}$ or Speos Artemidos. ${ }^{66}$

from the Henket-ankh has so far been identified as part of thirty-two sided columns, which are known from the Temple of Thutmose III at Deir el-Bahari (Niedziółka 1998). In this temple, while the columns with sixteen sides were used in the hypostyle hall, the Bark Hall, the 'room with four columns' and the portico located in front of the large hall, those with thirty-two sides were placed in the central part of the hypostyle hall (Lipinska 1977: 16-17). At least some of these display two decorated faces. All the inscriptions are carved in sunk relief painted with yellow colour and they have the same orientation to the right (Niedziółka 1998; Lipińska 1977). As we already point out above, Ricke suggested that the peristyle of the Henket-ankh could also have had on its main axis a row of columns larger than those located to the south and to the north (Fig. 1, reconstruction B) (Ricke 1939: 14, Pl. 6). Nevertheless, nothing proves it so far. In the Akh-menu at Karnak, the decorated sides of columns face the central south-north axis. The decorated sides of the eastern columns face to the west and the inscription is oriented to the left. The western ones face towards east and the inscription is oriented to the right (Pecoil et al. 2000: 26, Plan III, Pls 12-16).

${ }^{60}$ Bernhauer 2005: 46-52; Phillips 2002: 20; Beaux 2016: Pls 3, 12 (vol. I); Figs 5-26 (vol. II).

${ }^{61}$ In this temple at the entrance to the hypostyle hall Hathoric square pillars are attested along the axis on both south and north sides, while the hypostyle itself included columns topped with Hathoric capitals with the faces of the goddess represented on the east and west sides. There is also evidence of Hathoric heads in pilasters in the Chapel of Hathor of Thutmose III temple at Deir el-Bahari. These capitals were slightly smaller than those from the Chapel of Hathor in the Temple of Hatshepsut (Lipińska 1977: 38-45; Caban 2015; Dolińska 2015). Other New Kingdom examples of Hathoric capitals are known, for example, from the chapel dedicated to Tuy and Nefertari in a complex located on the northern side of the Ramesseum (Desroches-Noblecourt 1990/1991). Square pillars with Hathoric capitals are known also from the hypostyle hall of the smaller temple at Abu Simbel devoted to the queen Nefertari, as well as from the Temple of Montu and that of Mut at Karnak. This type of capitals are much more popular in the Ptolemaic period due to the increasing importance of Hathor cult.

${ }^{62}$ For an overview of Hathoric capitals as architectural and symbolic elements, see the comprehensive study of Bernhauer 2005.

${ }^{63}$ Bernhauer 2002.

${ }^{64}$ Bernhauer 2003.

${ }_{65}^{65}$ Petrie 1906: 100-103, 111, 142, Pl. 95.

${ }^{66}$ Chappaz 2014 


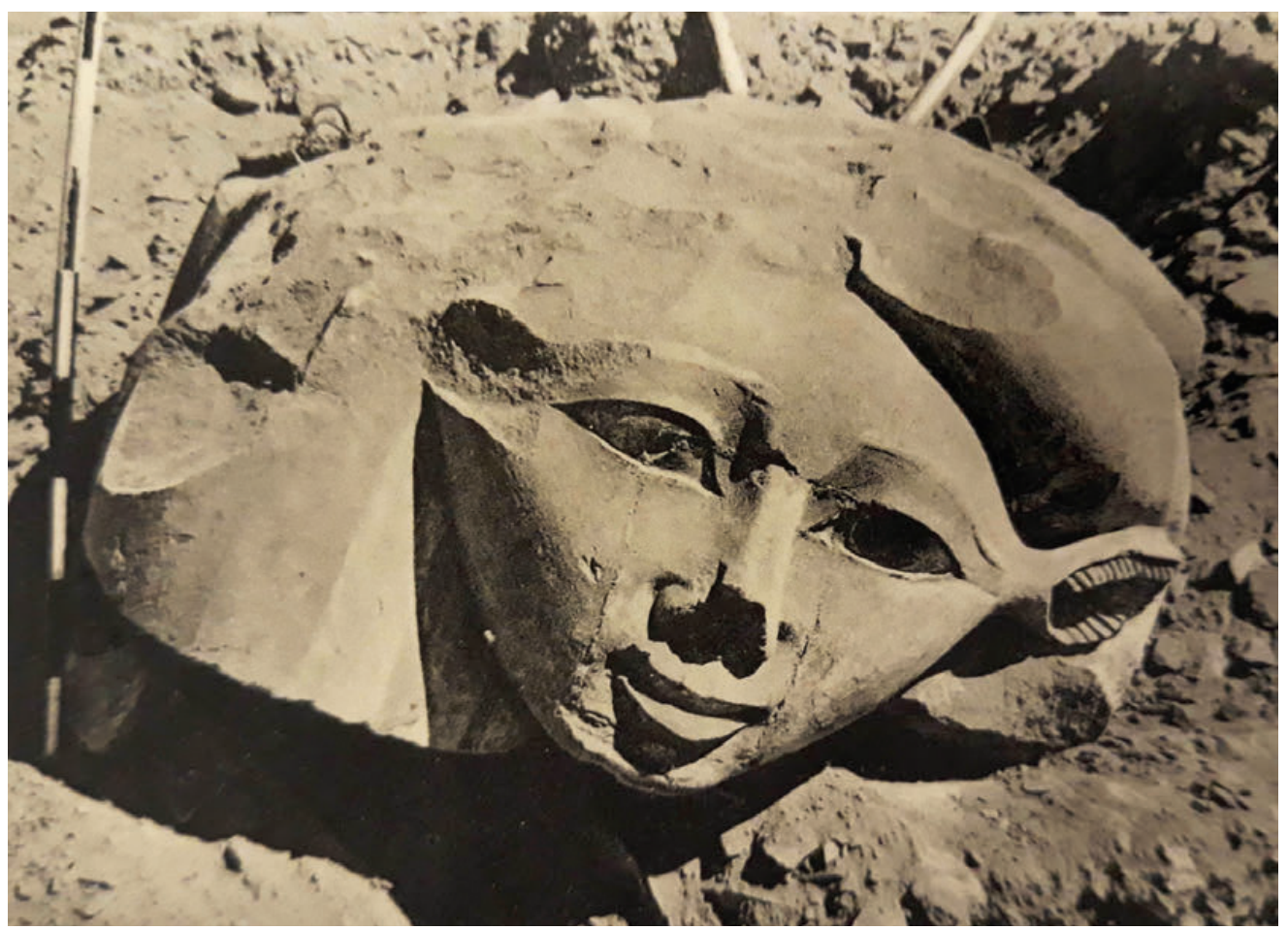

13. Hathor head, probably part of a Hathoric capital, discovered by Ricke on the site in the area of Hathor chapel (Ricke 1939: Pl. 3c).

In the area of the chapel of Hathor of the Henket-ankh, Ricke discovered what seems to be a fragment of a Hathoric capital (Fig. 13). ${ }^{67} \mathrm{He}$ published a photography of the capital in the spot where it was found, without, however, providing its dimensions. Edith Bernhauer $^{68}$ studied a Hathoric capital which is probably the one mentioned by Ricke. ${ }^{69}$ On its two sides the face of Hathor was represented. On the side shown on the photography published by Ricke, the middle of the face, area encompassing base of the eyes, nose and mouth, is clearly repaired. However, this part of the capital is currently lost. The top of the right side and the bottom of the left side of the wig is broken, as well as the right ear. On the other side of the capital, the top-left side and bottom right-side of the wig is broken, as well as the top of the left ear. The chin and the nose are slightly damaged. The top of the capital is completely missing. The dimensions of the piece are: $82 \mathrm{~cm}$ height, $114 \mathrm{~cm}$ wide and $110 \mathrm{~cm}$ thick.

${ }^{67}$ Ricke 1939: 21, Pl. 3c.

68 Bernhauer 2005: 63-65.

${ }^{69}$ The piece was exposed in the portico of the Metropolitan house at Deir el-Bahari and then moved to Al-Arish National Museum with registration no. 161. I would like to thank Jadwiga Iwaszczuk for her comments concerning the location of this Hathoric capital. In this regard, I am also grateful to Hesham Hussein, Director-General of North Sinai Antiquities and Mohamed Helmi Essa from Sohag University. 


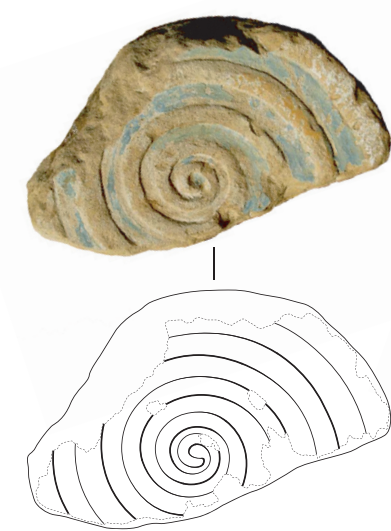

inv. no. 52
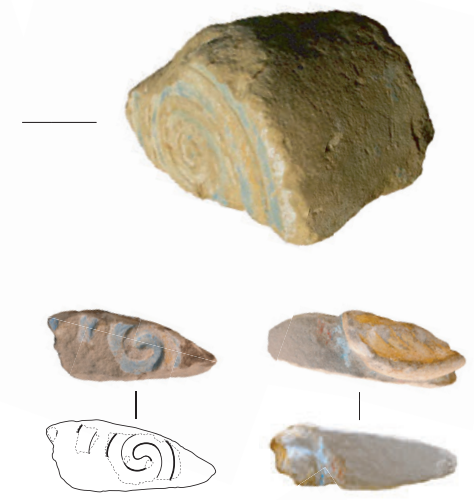

inv. no. 3275

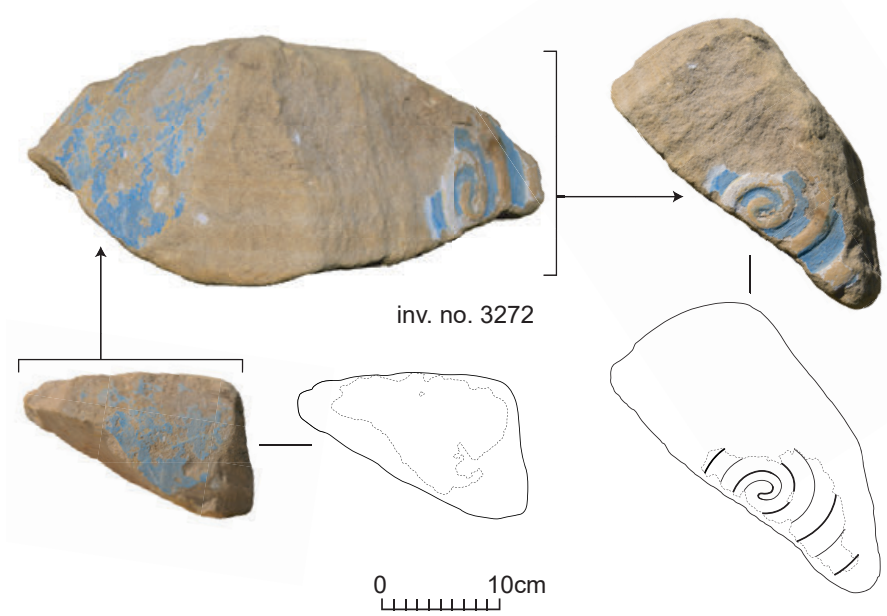

14. Fragments of Hathoric capitals discovered in the area of Hathor chapel by the Thutmosis III Temple Project (Phot. and drawing: L. Chapon (C) Thutmosis III Temple Project).

Moreover, three sandstone fragments (inv. nos 52, 3272, and 3275, Fig. 14) discovered at this site were recently identified as most likely remnants of spirals flanking the shrine topping this kind of capital. Another fragment may belong to part of a left ear. It preserves yellow colour inside the ear and remains of red in the area of wig (inv. no. 3229, Fig. 14). On all these fragments the spirals have rounded side faces. If we compare them with the capitals from the Chapel of Hathor in Hatshepsut temple at Deir el-Bahari, it could be suggested that most probably these fragments came from the upper part of columns and not from the pillars, since side faces of capitals topping the pillars are completely flat and they are crowned with the Horus name of the king. Therefore, it is possible to reconstruct that the columns on eastern and western side of the hypostyle of the Chapel of Hathor in the Henket-ankh 
had capitals with a Hathor head, crowned by a shrine, which was flanked by spirals on both west and east sides. The above-discussed fragments could belong to one or different columns. Also, the morphology of the capital discovered by Ricke seems to correspond to a column with the typical vertical fluting of the wig. The colour of the fragments identified during recent works at the site is very well preserved and it is identical to that preserved on above-mentioned capitals from Deir el-Bahari. The spirals are yellow with a red borderline and the background is blue. It is impossible to reconstruct if there were two or a single uraeus inside the shrine. ${ }^{70}$

Although it is possible to hypothetically reconstruct how these columns with Hathoric capitals may have looked like (Fig. 15), it should be noted that the reconstruction is based only on few small fragments. Generally, the head of the goddess in this type of capital was topped by a small naos-sistrum sound-box, although in the discussed collection this part has not been identified so far. The Hathoric capitals could be supported by circular columns, as well as polygonal or square pillars. ${ }^{71}$ The diameter of these columns could have been $c .90 \mathrm{~cm},{ }^{72}$ while the capital $c .147 \mathrm{~cm}$ wide and $232 \mathrm{~cm}$ high and $110 \mathrm{~cm}$ thick. ${ }^{73}$ They were, therefore, most probably smaller than the examples from Deir el-Bahari. The total height of the columns, including the shaft and the capital, may have been around $530 \mathrm{~cm}$.

On inv. no. 791 (Fig. 16) vertical bands with the red-blue-green colour sequence, separated by fine white lines, are clearly visible. The fragment may belong to the shaft of a column or to the bottom part of the wig from the Hathoric capital. It seems that surface on the fragment is slanted on the left side and that the 'lines' are slightly curved. ${ }^{74}$

Among other fragments corresponding to circular shafts of columns, most have been found either in the area of the Chapel of Hathor or in secondary de-contextualised deposit. Even if their original context is difficult to determine, it is possible to suggest that these fragments were part of columns from the Chapel of Hathor. ${ }^{75}$ Among circular column fragments only one, inv. no. 1521 (Fig. 16), retains part of a vertical inscription, which could be identified as the birth name of Thutmose III. The text is carved in sunk relief and painted yellow. Nevertheless, the size of the inscription indicates that this fragment was probably part of a small column attached to a pilaster and not of the circular shafts that probably supported the Hathoric capitals presented above. Another fragment (inv. no. 3419, Fig. 16)

70 There are two uraei on the capitals from the Chapel of Hathor in Hatshepsut temple at Deir el-Bahari, and one - according to the reconstruction - on capitals from the Chapel of Hathor in Thutmose III temple (Caban 2015; Dolińska 2015; Beaux 2016: Fig. 26).

71 Bernhauer 2005; Phillips 2002: 20. This kind of columns are already attested in the Middle Kingdom, but in the New Kingdom they further developed. The form of Hathoric capitals was changing in the time and between monuments (Phillips 2002: 20).

72 Ricke 1939: 22.

73 The thickness is reconstructed on the basis of Hathoric capital found by Ricke.

74 See for comparison the Hathoric capitals from the Chapel of Hathor in the Temple of Hatshepsut (Beaux et al. 2016: Figs 10, 15, 17, 18 and mostly 22 (vol. II)).

75 Nevertheless, we cannot exclude the possibility that these fragments of circular shafts of columns may be related to another part of the complex, for example to the first court. 


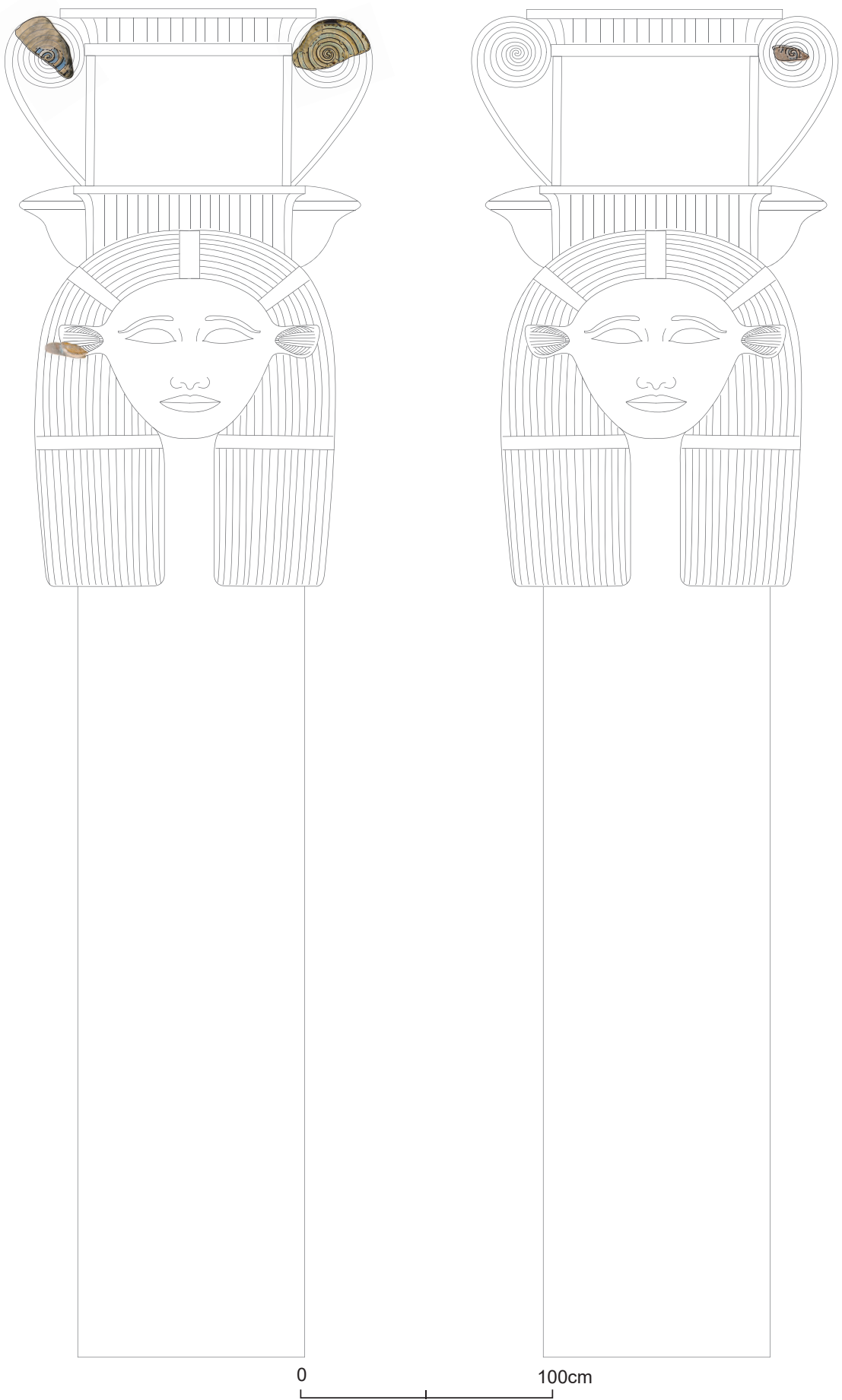

15. Hypothetical reconstruction of Hathoric capitals crowning circular columns; based on the fragments discovered in the temple (Drawing: L. Chapon $\mathbb{C}$ Thutmosis III Temple Project). 


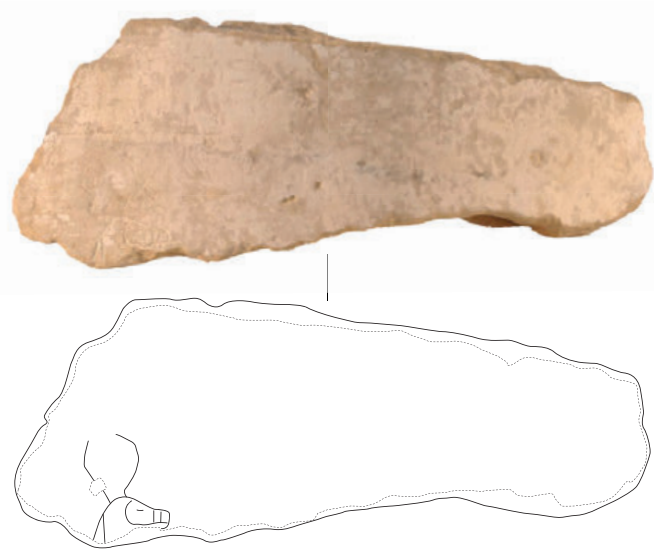

inv. no. 3419

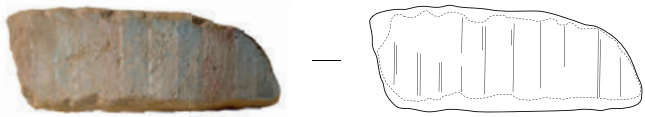

inv. no. 791

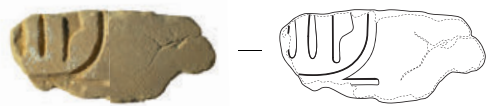

inv. no. 1521

0 $10 \mathrm{~cm}$

16. Fragments of circular shafts of columns (Phot. and drawing: L. Chapon (C) Thutmosis III Temple Project).

shows a plastered surface and a graffito made on an undecorated surface. Since it depicts probably the head of ram of a portative divine barque of Amun, it could be related to a procession that included this divinity.

\section{FRAGMENTS OF PILLARS}

Many fragments of sandstone discovered in the Henket-ankh were identified as corners of square pillars. They are generally small and none of them retains all four sides. The findspot of the fragments does not provide any satisfactory indication as to the localisation of these pillars within the temple. However, most of them were discovered in the second court. These fragments could be organised into three groups according to the type of relief covering them:

- group 1: two faces in bas-relief (Fig. 17);

- group 2: one face in sunk relief and one in bas-relief (Fig. 18);

- group 3: two faces in sunk relief (Fig. 19). 


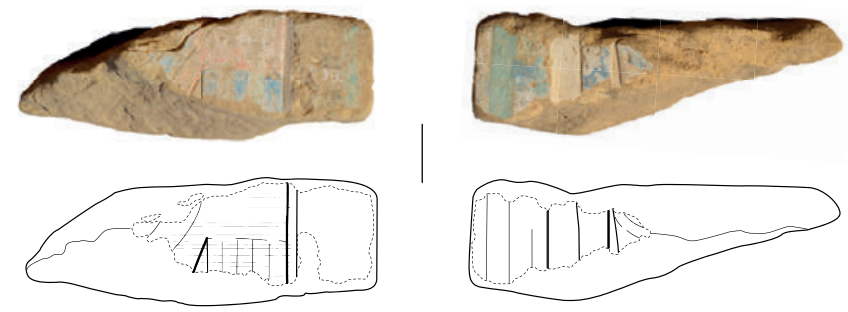

inv. no. 1141
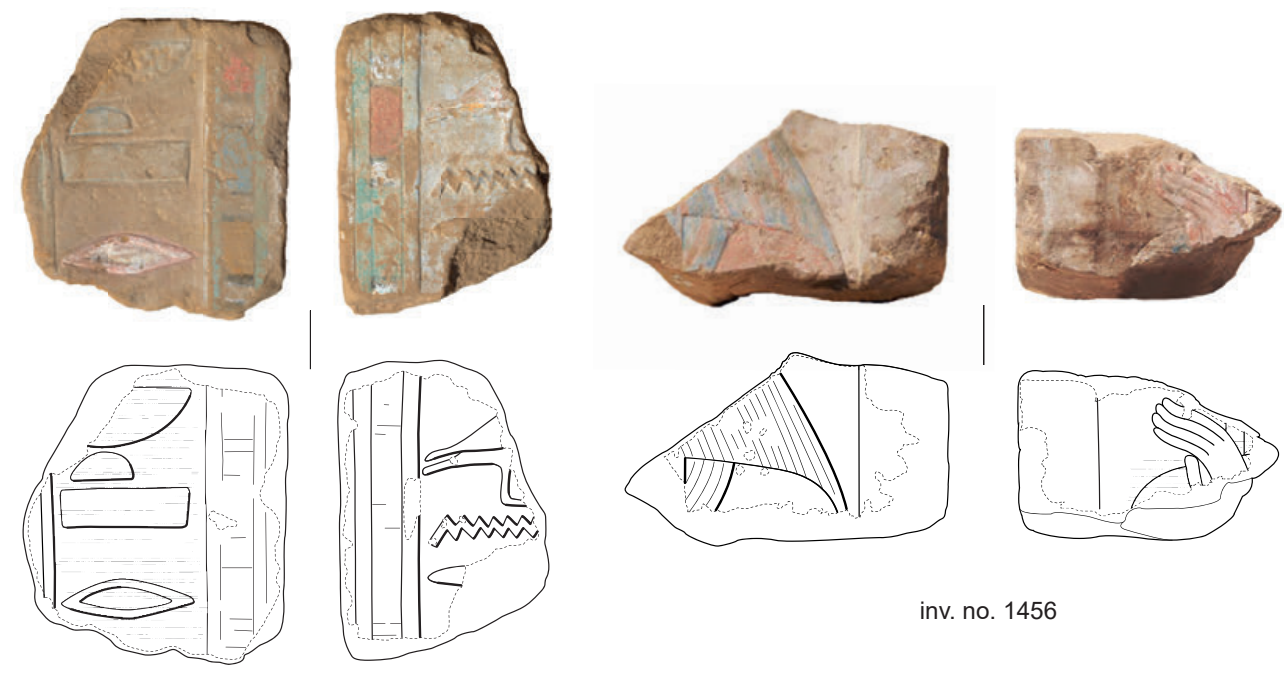

inv. no. 1143
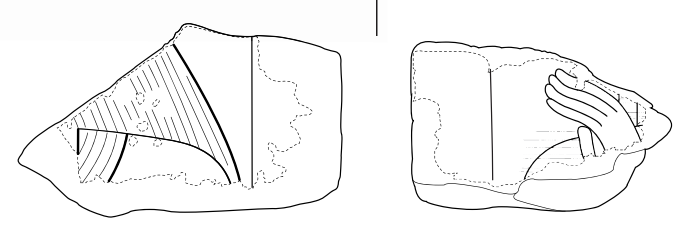

inv. no. 1456

17. Fragments of pillars with two sides decorated in bas-relief (Phot. and drawing: L. Chapon (C) Thutmosis III Temple Project).

An attempt has been made to use these fragments to propose a reconstitution of how these pillars may have looked like. Other monuments show several patterns as to the type of applied relief on particular sides of the pillars, and this data can certainly help in reconstruction of the localisation of particular pillar fragments. In several monuments, it is possible to observe that the faces oriented towards inside of the complex were decorated in bas-relief and the faces exposed to the sun in sunk relief. ${ }^{76}$ In such a case, one face was decorated in bas-relief and three in sunk relief. Pillars decorated in this manner are situated in the entrance or on the axis of a temple, ${ }^{77}$ or even they can surround a free standing

76 This is the case of the portico of the Temple of Thutmose III (Lipińska 1977: 47-50) or also the pillars from the ambulatory surrounding the Bark Hall of the Eighteenth Dynasty temple at Medinet Habu (Hölscher, Anthes 1939: 19, Pls 18-20).

77 For example, in the Temple of Satet at Elephantine. 

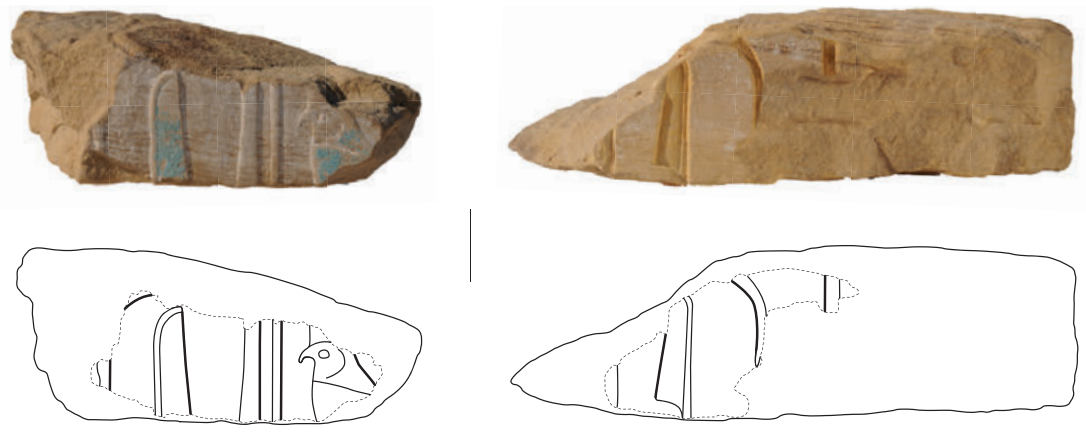

inv. no. 3254

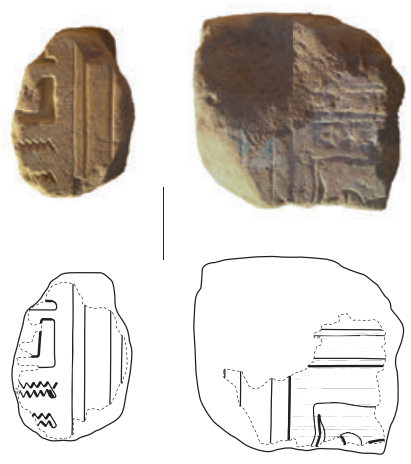

inv. no. 1687
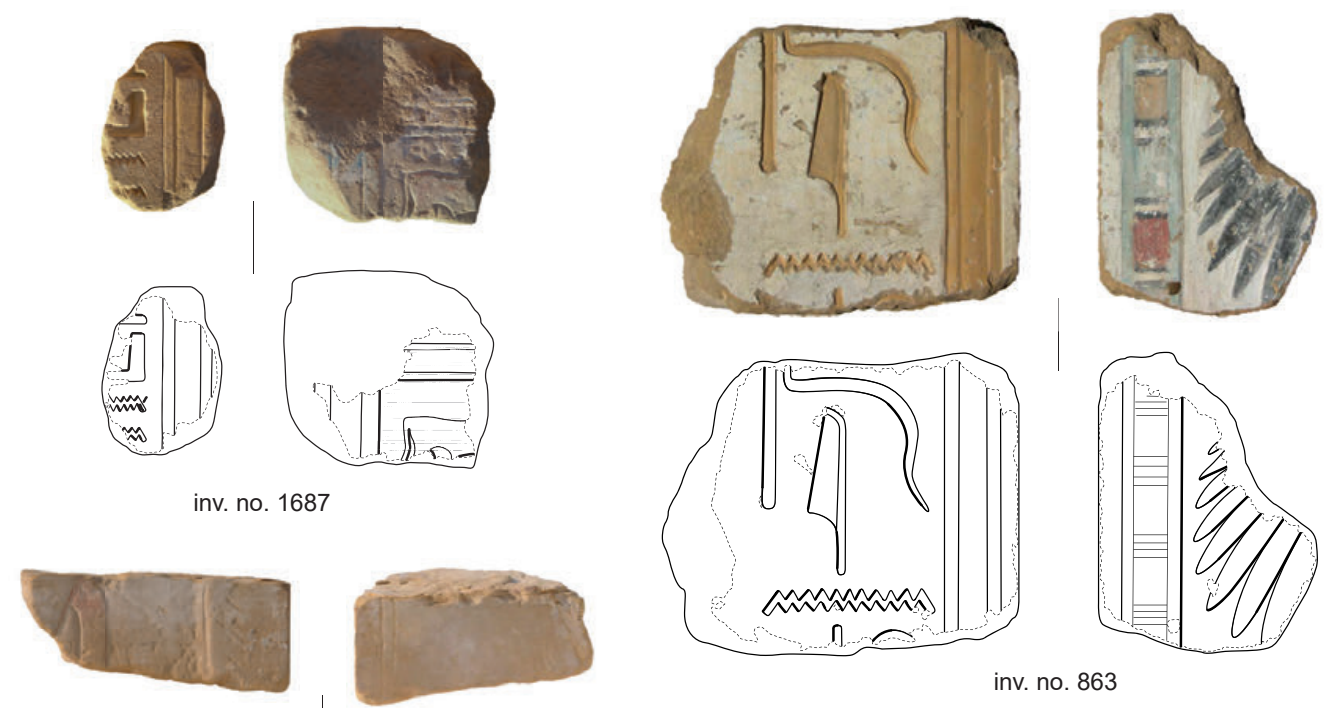

inv. no. 863
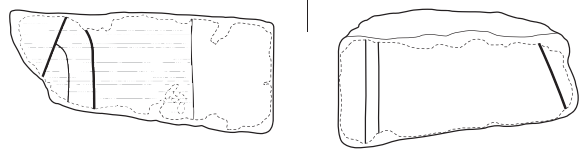

inv. no. 142
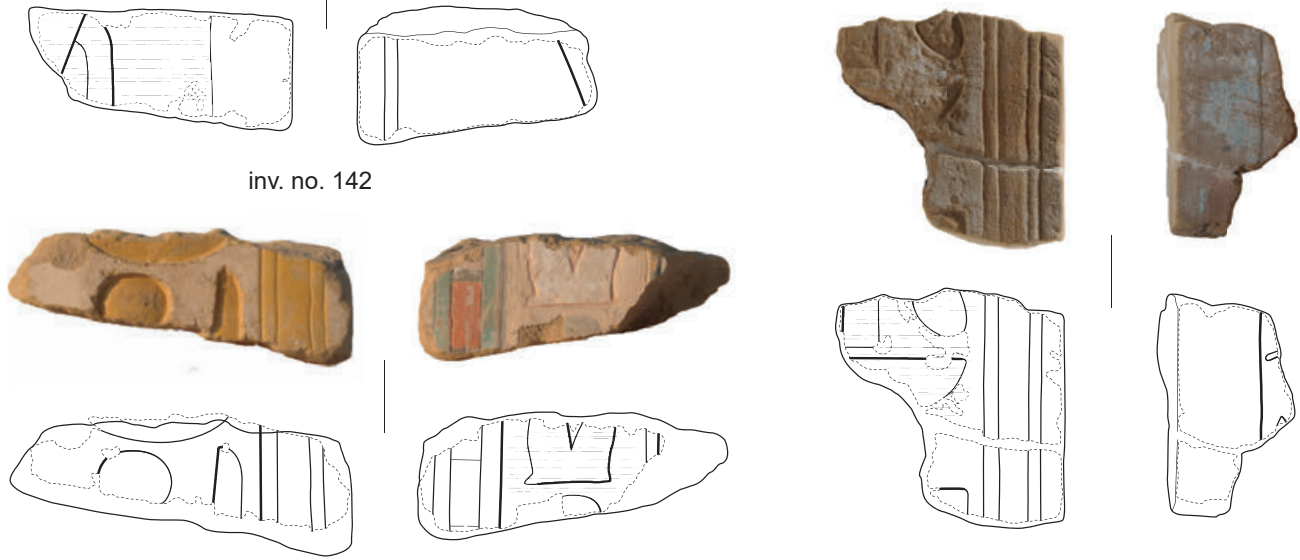

inv. no. 1128

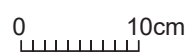

inv. no. $1507-219$

18. Fragments of pillars with one side decorated in bas-relief and the other in sunk relief (Phot. and drawing: L. Chapon (C) Thutmosis III Temple Project). 

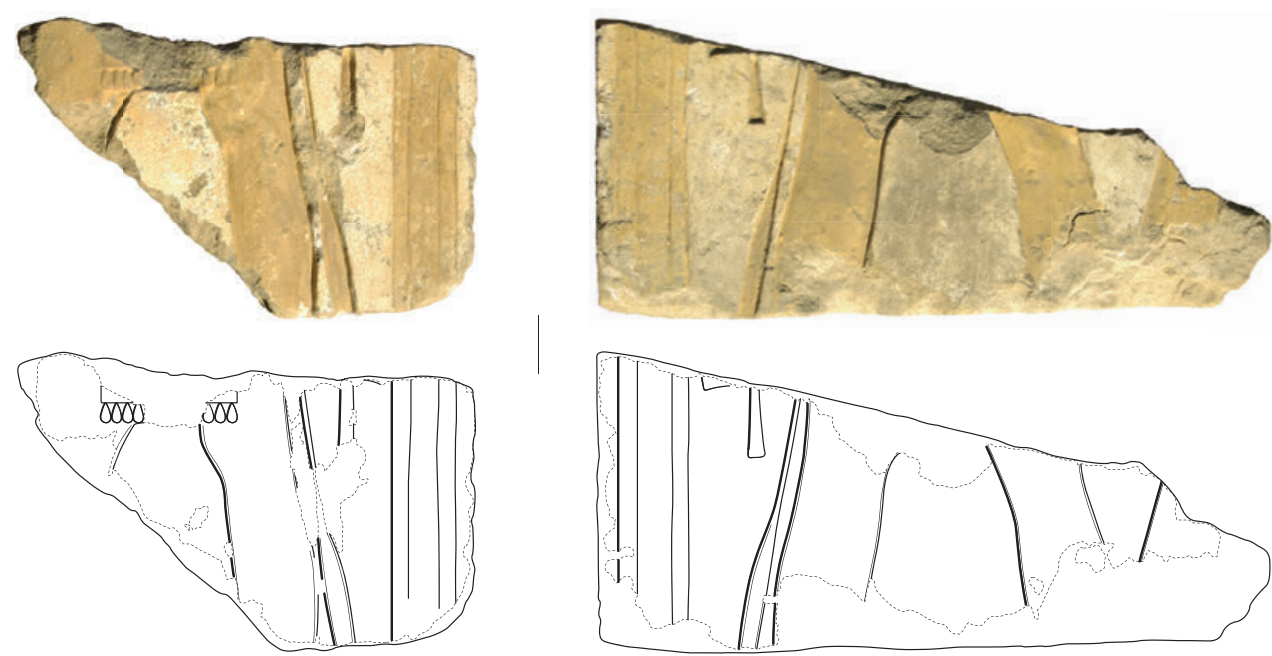

inv. no. 10798
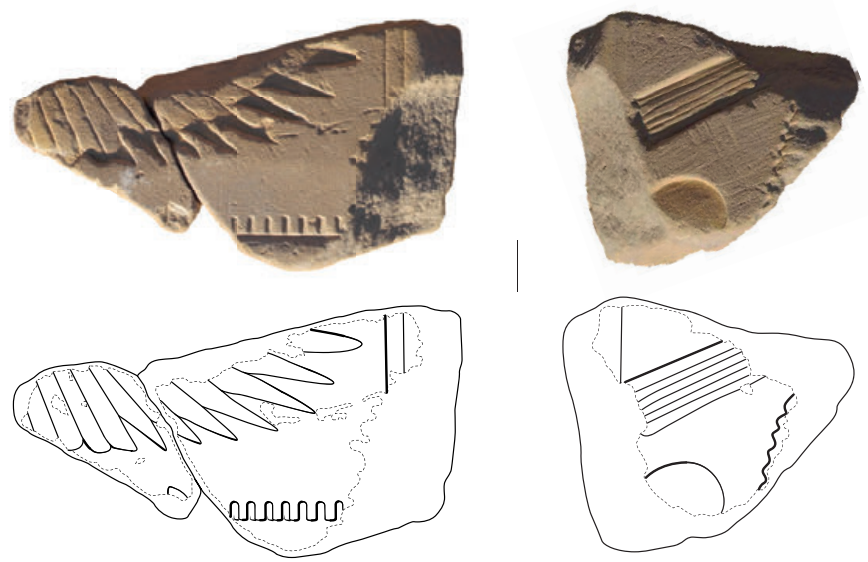

inv. no. $216-1580$
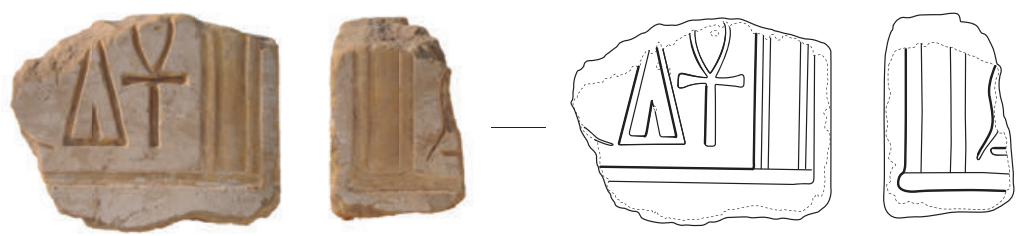

inv. no. 525

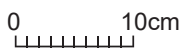

19. Fragments of pillars with two sides decorated in sunk relief (Phot. and drawing: L. Chapon $($ C Thutmosis III Temple Project). 
structure. ${ }^{78}$ However, pillars decorated on all sides in bas-relief (group 1) are also known, particularly from the inner parts of temples including an open court. ${ }^{79}$

One should also note that, in case of Osiride pillars, one side was covered, by the statue, and therefore usually does not show any scenes. However, sometimes there might be inscription on the pillars behind the head of the statue, as happens in Deir el-Bahari where the royal protocol appears in sunk relief behind the statue. On the other hand pillars with two sides decorated with scenes with the kings and gods carved in sunk relief, should not, theoretically, be part of Osiride pillars. Available archaeological data quite clearly suggest that the main portico of the temple, situated on the upper terrace, was composed of ten Osiride pillars that were not followed by a second row of pillars. Consequently, both the northern and southern sides of these pillars should have been carved in sunk relief while the western face in bas-relief (group 2) (Fig. 20a).

As we have already seen, it is possible that a wall or a single row of pillars existed in the second court, in front of the upper terrace. If in this spot were pillars, they most probably corresponded to groups 2 and 3 , that is to say these were pillars with the western side decorated in bas-relief and the three others in sunk relief.

According to Ricke hypothetical plan A and B, a row of pillars could have been situated in the entrance area to the Chapel of Hathor (Figs 1, 3). These pillars could have corresponded to groups 2 and 3. However, in hypothetical plan C, he proposes two rows of pillars. In this case, the pillars could have had the four faces in bas-relief, or maybe one in sunk relief and three in bas-relief. They would thus correspond to group 1, with two sides in bas-relief. The preserved fragments of pillars seem to corroborate reconstruction C (Fig. 20b).

Despite the poor state of preservation of fragments of pillars from the Henket-ankh, it is possible to partially reconstruct how these architectural elements were originally decorated. The figures depicted on the pillars were $c .110 \mathrm{~cm}$ high, the decorated parts of pillars were at least $315 \mathrm{~cm}$ high and finally the width of the pillars were between 75 and $80 \mathrm{~cm}$ (Fig. 21). This is the same width as in case of the pillars from the Temple of Hatshepsut, so, fragments from the Henket-ankh were prepared according to the architectural module applied in the times of Hatshepsut ( 1.5 cubit).$^{80}$ It is so far impossible to ascribe the particular fragments to specific pillars and then to count a minimum number of pillars. However, it is possible to place some of them on particular faces of pillars (Fig. 20c).

The winged deities, Horus of Behedet (inv. no. 216-1580, Fig. 19) in the form of the hawk, and Nekhbet/Wadjet in the form of a vulture were depicted on the upper part of the pillars. They are found on all known pillars of this period. The fragments from the Henket-ankh indicate that the names of these deities had to be written, at least on certain pillars (group 3), on the upper part, in a line placed above the winged deity (inv. no. 216-1580, Fig. 19).

\footnotetext{
${ }^{78}$ See pillars surrounding the barque station of Khnum at Elephantine (Bommas 2000: 423-429, 432-434).

79 See, for example, portico of Thutmose IV, today reconstructed in the open-air museum at Karnak (Letellier, Larché 2013: Pls 86-175).

${ }^{80}$ Karkowski, Wysocki 1975: 342-343; Połoczanin 1980: 85-87; 1985; Wysocki 1990; Carlotti 2005: 183$185,187$.
} 


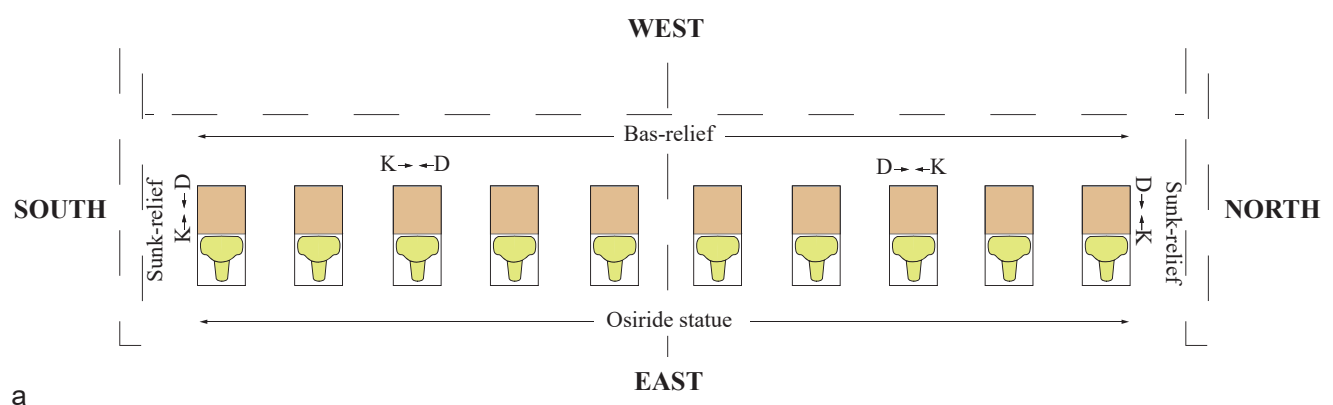

a

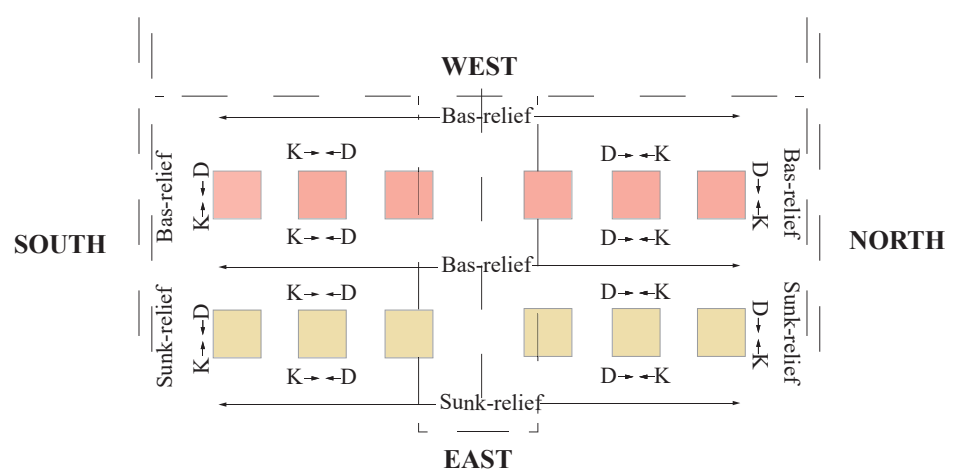

C

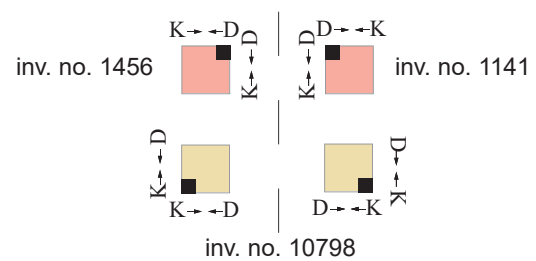

20. Decorative scheme of pillars from the Henket-ankh ( $\mathrm{D}=$ divinity; $\mathrm{K}=$ king): a. portico of the main temple; b. portico of the Chapel of Hathor according to Ricke's reconstruction C; c. localisation of some of the fragments on specific pillars (Drawing: L. Chapon (C) Thutmosis III Temple Project).

This is suggested by the composition of the representation. Since the wings of the deity touched the opposite edges of the face of the pillar and solely the name of the divinity which was facing the king (see below) appears here, the only place left to give the name of winged deity is, therefore, the upper part of the pillar. ${ }^{81}$

The scenes from the pillars shows invariably a divinity heading towards the king, embracing him or even offering him the ankh-symbol. ${ }^{82}$ The divinity is oriented outwards,

${ }^{81}$ See pillars from the Temple of Hatshepsut at Deir el-Bahari (Naville 1898: Pls LXV, LXVI). On the pillars from the Akh-menu, the name is shown at the same level as the figure. In the porticoed courtyard of Thutmose IV at Karnak, the name may appear above the winged divinity or on the side of the pillar (Letellier, Larché 2013: Pls 86-175). In all cases, except for the Akh-menu, a horizontal inscription is included on the upper part of the pillars.

${ }^{82}$ Myśliwiec 1985; Haeny 1997. 


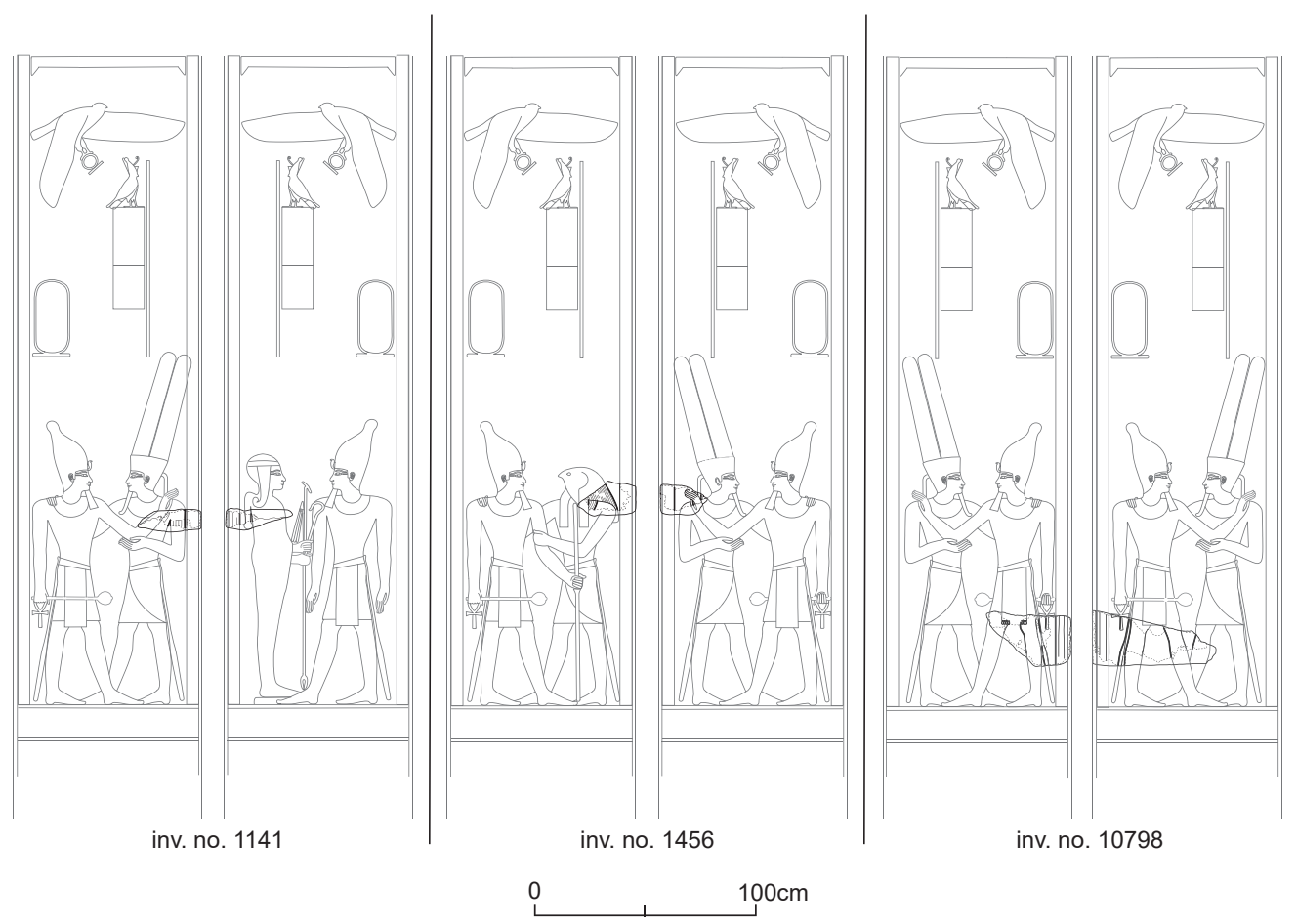

21. Reconstruction of decoration of pillars based on fragments discovered in the temple (Drawing: L. Chapon (C) Thutmosis III Temple Project).

as if it came out of the temple, and towards the south, north or east, while the king heads inwards, towards entrance and the central axis (Fig. 20). It is likely that the royal figures represented on the pillars of the southern half of the temple were depicted with the White Crown or the Double Crown and those on the northern half, with the Red Crown or the Double Crown, as it is the case at the Akh-menu. ${ }^{83}$ The largest block (inv. no. 10798, Figs 19, 21) that has been discovered in the temple belongs to the group 3 with two sides in sunk relief. On each side the legs of the king and the divinity can be noted. So, it is possible to identify this block as a south-eastern corner of a pillar placed on the southern side of the central axis, or as a north-eastern corner of a pillar placed on the northern side of the axis (Fig. 20c). The king's hand appears for example on inv. no. 1456 (Fig. 17) and inv. no. 3565 (Fig. 22). Some reliefs, such as inv. no. 3348 (Fig. 22), retain only one side, but they can, thanks to the size and the decorative scheme, be attributed to pillars. The orientation of the remaining decoration of the pillars followed the same decorative rules.

At least for part of the pillars from group 2, that is those that show one side in bas-relief and one side in sunk relief, the inscription located above the king and the deity indicate

${ }^{83}$ Barguet 1962: 170-171. 


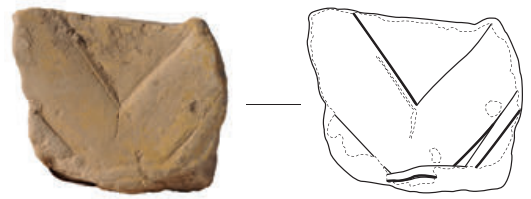

inv. no. 3348

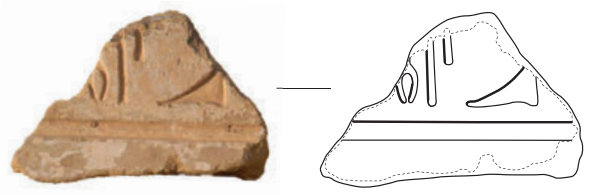

inv. no. 1206

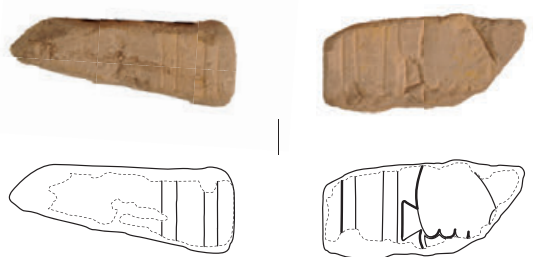

inv. no. 3565

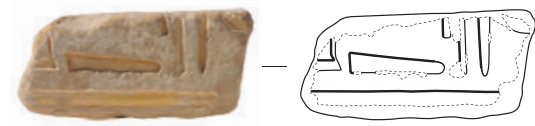

inv. no. 1534

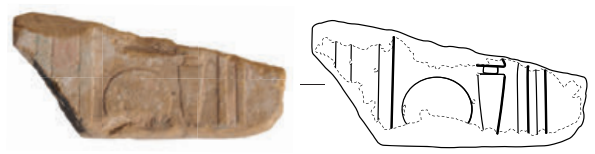

inv. no. 138

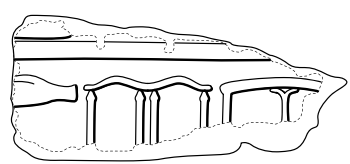

inv. no. 1397

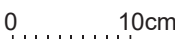

22. Fragments of probable pillars with only one side preserved (Phot. and drawing: L. Chapon (C) Thutmosis III Temple Project).

that they most probably have been similar to those known from the second terrace of the Temple of Hatshepsut at Deir el-Bahari and some from the porticoed court of Thutmose IV in Karnak. The text included consecutively the cartouches of the king accompanied by protection formulas, the Horus name included in the serekh, with the formula ' $d d m d w$ $j n[\ldots]$ ' followed by the name and epithets of the divinity facing the king or by various wishes offered to the king (see, for example, inv. nos 863 and 3254; Fig. 18). Some fragments document different formulas. On the left side of inv. no. 1687 (Fig. 18), it is possible to read '[...] dj.n(.j) $n .[\ldots]$ ', '[...] I gave you [...]', while the name of the manifestation Amun-Kamutef appears on the right side. ${ }^{84} \mathrm{~A}$ different version is preserved on inv.

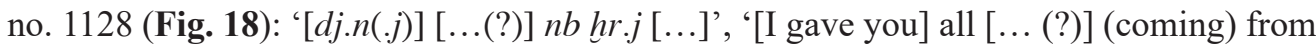

${ }^{84}$ It does not seem to be the Horus name of the king since the sign is not framed. In addition, it seems that the sign was probably erased in the Amarna period and then restored. 
me $[\ldots]{ }^{3}{ }^{85}$ Amun's name is on the left side. On fragments showing two sides in sunk relief (group 3), still different formulas have been identified: '[dj.n(.j)] [...(?) $n b] h[r] j.[\ldots]$, '[I gave you all ...(?) (coming) from me]' or '[dj.n.j] $n$ hsswt [nbt (?)]' '[I gave you all] foreign countries' ${ }^{86}$

Next to the winged deity, there were several columns of inscriptions that included the names of the king: the Horus name, the birth name (inv. no. 1143, Fig. 17) or the throne name, as well as the name and epithets of the divinity who was facing the king. On inv. no. 1143, for example, one of the faces of the pillar preserves part of the title often accompanying the birth name: ' $z 3$ n $h t .[f]$ '.

The god Amun was certainly the main divinity depicted on these pillars. Some of the fragments preserving part of the skin of this divinity show a blue colour (inv. no. 1456, Figs 17, 21), but it possible that the skin was sometimes also painted red ${ }^{87}$ The name of this deity appears on different fragments of pillars. In one case, his name is accompanied by the epithet ' $n b n s w t$ '. In all cases Amun name was hammered and then restored. His crown has been identified on, for example, inv. no. 142 (Fig. 18). It should be noted that on pillars from some temples, only Amun appears in front of the king. ${ }^{88}$ In the case of the Henket-ankh, and some other temples, ${ }^{89}$ also other divinities were depicted in front of the pharaoh.

A male god appears, for example, on one side of inv. no. 1456 (Figs 17, 21). On the other face of the fragment, Amun is embracing the king whose hand is resting on the shoulder of the god, painted blue. Since in the Akh-menu, for example, Horus of Behedet is always represented on the south while Horus the Elder on the north, we may propose that this was Horus the Elder depicted here and this was at the same time the north side

$85 \mathrm{~Wb}$ III: 315,10 . This expanded formula for expressing the gifts that the divinity made to the king is found several times in the temples of this time. In the Temple of Hatshepsut at Deir el-Bahari, it is attested on a pillar from the middle portico; it presents the version 'dj.n.(j) $n . k$ [ $\left.{ }^{\top} n h \underline{d} d d w 3 s\right] n b h r . j$ snb $n b h r . j 3 w t-j b n b h r . j$ ' (Naville 1898: Pl. LXVI, pillar shown in the middle). This expression is, among others, also known from the pillars of the White Chapel of Sesostris I in Karnak (Lacau, Chevrier 1956: 118-120 (vol. I); Pl. 32 (vol. II); Arnaudiès, Beaux, Chéné 2015: P1. 32). This is an expanded version of 'dj.n.(j) $n . k$ ' $n h$ dd $w 3 s n b$ hr.j’. It also appears on certain pillars of the porticoed court of Thutmose IV in Karnak (Letellier, Larché 2013: Pls 98-99, 102-103, 152).

${ }^{86}$ Some of these fragments have been already published in: Chapon 2018a: Fig. 8.

${ }^{87}$ On reliefs from the Henket-ankh, Amun is most often shown with a red skin.

${ }^{88}$ For example, in temples of Hatshepsut (Naville 1898: Pls LXV-LXVI) or Thutmose III (Lipińska 1977: 47-50) at Deir el-Bahari or in the porticoed courtyard of Thutmose IV in Karnak (Letellier, Larché 2013: Pls 86-178).

${ }^{89}$ On virtually every pillar from the Akh-menu, at least one divinity other than Amun is represented on one side. The orientation of this side varies and depends on the divinity and the position of the pillar (Pecoil et al. 2000: Pls 17-78). Among well preserved representations of gods with inscribed name should be enumerated: Horus of Behedet (Pecoil et al. 2000: Pls 23, 27, 37, 59), Montu (Pecoil et al. 2000: Pl. 41), Horus (Pecoil et al. 2000: Pls 33, 65), Khonsu (Pecoil et al. 2000: Pls 33, 59, 78), Geb (Pecoil et al. 2000: P1. 43), Hathor (Pecoil et al. 2000: Pls 20, 31, 35, 39, 43, 63, 73), Mut (Pecoil et al. 2000: Pls 35, 39, 45, 57, 65, 69, 76), and Amunet (Pecoil et al. 2000: Pls 41, 49). They are represented in the act of giving the sign of life to the king or while supporting the arm or head of the king. In the case of Khonsu, the deity and the king are embraced. 
of a pillar placed south of the central axis. ${ }^{90}$ Consequently, Amun was represented on the west face. ${ }^{91}$ On inv. no. 1141 (Figs 17, 21), a divinity with a red polychromy appears on the left side, while Khonsu probably appears on the right side. A goddess is depicted also on another fragment (inv. no. 1143, Fig. 17) together with the epithet of Mut: ' $[m w t] n b t$ $j \check{s} r[w$.... $]{ }^{9}{ }^{92}$ On fragment inv. no. 1507-219, Isis has been documented (Fig. 18): '3st $n b[t]$ $p t(?)$ ', 'Isis, mistr[ess] of the sky'.

The lower part of the pillars included typical formulas that are found also, for example, on pillars from the Temple of Hatshepsut at Deir el-Bahari. ${ }^{93}$ However, it is impossible to reconstruct whether there were one or two lines of inscription under the figures. These inscriptions were composed either of standard formulas offered to the king: '[ $\ldots d j]$ ' $n h \underline{d} \underline{d} d$ w3s snb [...]' (inv. no. 525, Fig. 19; inv. nos 132, 1206, Fig. 22) or of the wish to celebrate 'millions of sed-festivals' and 'the first occasion of the sed-festival [he did...]': 'zp tpy $h b$-sd [jr.f...]' (inv. nos 138, 1397, 1534, Fig. 22). Since fragments with both the first and the second formula correspond to the line just below the figures, most probably only a single line of text existed there, at least on some of the pillars. The two types of formula would then have alternated on the pillars, as at the Akh-menu. Each side surface of the pillar, down to the inscription, was flanked by vertical frame made in bas- or sunk relief. On the other hand, the lower part of the side of pillars decorated in bas-relief (group 1 and 2) show horizontal lines, typical for the lower part of decorated walls of this period, while sides engraved in sunk relief (group 2 and 3) show only a simple line.

\section{SUMMARY}

The great majority of the vertical architectural elements with support function coming from the Henket-ankh have been lost. The preserved fragments are generally small and their original location usually cannot be precisely enough determined. Nonetheless, they allow a reconstruction to some extent the arrangement of vertical elements with support functions within the temple and, consequently, also a comparison of their decorative programme with decoration of other better-preserved temples.

The vestibules leading to the sanctuary area, the hypostyle with the side rooms, and the peristyle of the main part of the temple included polygonal columns. A row of such columns could have been also located behind the Osirian pillars in the main portico, if one assumes that this row truly existed. Until now, it has not been confirmed that there

90 To be precise, according to the reconstructed general outline of the decoration scheme of the pillars, this could have been fragment of the pillar from the north-western corner of the southern half of the portico or from south-western side of the northern half of the portico.

91 The figures from this scene were reconstructed as embracing, although the position in which the divinity was originally represented remains unclear.

92 The name of Mut is followed by this epithet once on one pillar from the Heret-jb of the Akh-menu (Pecoil et al. 2000: P1. 35). This divinity is attested also on another pillar from this monument (Pecoil et al. 2000: P1. 39).

${ }^{93}$ Leblanc 1997. 
were columns with thirty-two sides in the temple. Only sixteen sided examples have so far been clearly identified. These columns showed probably a single vertical inscription on one of the faces. Not all these inscriptions are exactly the same. They included the Horus name of the king, the cartouches and several pharaohs epithets, as well as the name and epithets of Amun. Other gods also have been mentioned, but among them only Montu has been clearly identified. The inscriptions differ in colour but it has not been so far possible to define the reason behind this choice of paint.

Fragments of the Hathoric capitals, including one found already by Ricke and three further ones, recently identified, belonging to the top of at least one capital, confirm the application of such vertical supports in the Chapel of Hathor in the Henket-ankh. This chapel most likely dates to a last phase of construction of the temple, which took place by the end of the reign of Thutmose III. The decoration of the chapel was probably finished during the reign of Amenhotep II. Probably during the same period another chapel of Hathor was constructed in Deir el-Bahari.

Among the pillar fragments, three groups have been identified. Those with two faces in bas-relief (group 1) belonged most probably to a rear row of pillared portico, if one assume that this row truly existed in the Chapel of Hathor. Circular columns with Hathoric capital could have been placed inside the hypostyle of this chapel. Pillars with a face in bas-relief and the other in sunk relief (group 2) may have been fragments of Osiride pillars of the main portico. Originally their northern and southern sides could have been carved in sunk relief while the western face was in bas-relief. However, these fragments could also have belonged to a possible pillar façade in the second court or even to the pillars of the Chapel of Hathor, as was suggested for pillar fragments with two faces in sunk relief (group 3).

On each pillar the god Amun facing the king was represented. Amun could have been replaced in this role by other divinities, as on the pillars from the Akh-menu and pillars from the Eighteenth Dynasty temple at Medinet Habu. The above conducted analysis may suggests that on the pillars of the portico area only representations of Amun and pharaoh were attested, while on those from the possible Chapel of Hathor also other deities. However, in the Chapel of Hathor at Deir el-Bahari only Hathor and Amun are shown. Nevertheless, even if other deities were in fact represented on the discussed pillars from the Chapel of Hathor in the Henket-ankh it is impossible to reconstruct what deities could have been depicted there and on how many pillars. The scene of embracing the king and the god is the only one that has been so far documented on the pillar fragments from the temple.

The lower part of pillar's decoration contained standard formulas, such as the wish to celebrate 'millions of sed-festivals' and 'the first occasion of the sed-festival'. This kind of inscription is typical for the pillars. ${ }^{94}$ In the Henket-ankh, similarly as at Deir el-Bahari, the Akh-menu, and other foundations in Karnak (the Temple of Thutmose IV, the Chapel

${ }_{94}$ Redford (Redford 1986: 180) named them 'Pillar Benediction', since these formulas used to be placed on pillars. For the use and function of pillars with such inscriptions in Temples of Millions of Years, see: Leblanc 2010: 69-89. Close parallels may be found in the Middle Portico (Naville 1898: Pls LXV-LXVI) and in the Upper Portico (Karkowski 1980: 49, Fig. 5) at the Temple of Hatshepsut at Deir el-Bahari. Pillars placed in the Heret-jb of the Akh-menu show also the same features (Pecoil et al. 2000: Pls 17-78). 
of Sesostris I, the monument of Amenhotep II), only the form ' $z p$ tpy $h b-s d$ ' has been identified. These formulas correspond to a standard repeated hyperbolical construction used to express the wish to celebrate one or more festivals in the future. They were meant to contribute to the idea of eternal royal regeneration..$^{95}$ It should be underlined that there could have been some variations in the decoration of pillars, not only between specimens coming from different areas, but also between pillars from the same row, or even between different faces of the same pillar.

Finally, we should note that all the cartouches preserved on fragments of columns and pillars belong to Thutmose III. Only one block of column (inv. no. 4, Fig. 11) shows erasure of the surface and a re-carving with the throne name of Thutmose III as well as a feminine ending ' $t$ '. This evidence would suggest that the name of Hatshepsut was the one originally written here. The find-spot of this fragment, i.e. the hypostyle or the vestibule area, may indicate that this column was related to a first phase of construction of the temple. Only during this first phase, which most likely have taken place during the coregency of Hatshepsut and Thutmose III, the queen could have been included in the decorative program of the Henket-ankh. Anyhow, without doubts she was not represented in any way during later phases of temple construction, so in the times of Thutmoses III sole reign.

\section{Acknowledgements}

This paper partly results from the $\mathrm{PhD}$ thesis of the author, which was funded by Santander Universidades. The work would not have been possible without the support of the team of the Thutmosis III Temple Project and project director, Dr Myriam Seco Álvarez.

\section{References}

Arnaudiès, A., Beaux, N., Chéné, A. 2015: Une chapelle de Sésostris ${ }^{\text {er }}$ à Karnak, EtudEg 13, Paris

Arnold, Di. 1974: Der Tempel des Königs Mentuhotep von Deir el-Bahari: Architektur und Deutung, vol. 1, ArchVer 8, Mainz a/Rhein

Arnold, Di. 1979: The Temple of Mentuhotep at Deir el-Bahari, vol. 1, PMMA 21, New York

Badawy, A. 1968: A History of Egyptian Architecture. The Empire (the New Kingdom). From the Eighteenth Dynasty to the End of the Twentieth Dynasty 1580-1085 B.C., Berkeley-Los Angeles

Barguet, P. 1962: Le temple d'Amon-Rê à Karnak. Essai d'exégèse, RAPH 21, Le Caire

95 Bonhême, Forgeau 1988: 289; Hornung, Staehelin 1974: 63-65; 2006: 10-12, 41-42; Hornung 1991: 169-171. For a compilation of New Kingdom references to heb-sed wishes, see also: Birkstam 1974: 21-23. As they mentioned the heb-sed, this kind of specific formula have often been used as historical sources to prove the first celebration or actual planning of the sed-festival (Wente, Van Sinclen III 1976: 227; Murnane 1981: 369-376; Kitchen 1973: 302, 305). 
Beaux, N. 1995: La chapelle d'Hathor de Thoutmosis III à Deir el-Bahari, VarAeg 10/2-3, 59-66

Beaux, N. 2012: La chapelle d'Hathor. Temple d'Hatchepsout à Deir el-Bahari I. Vestibule et sanctuaires, fasc. 1 : Texte, MIFAO 129/1, Le Caire

Beaux, N., Grimal, N., Pollin, G. 2012: La chapelle d'Hathor. Temple d'Hatchepsout à Deir el-Bahari I. Vestibule et sanctuaires, fasc. 2 : Figures, MIFAO 129/2, Le Caire

Beaux, N., Karkowski, J., Majerus, E., Pollin, G. 2012: La chapelle d'Hathor. Temple d'Hatchepsout à Deir el-Bahari I. Vestibule et sanctuaires, fasc. 3 : Planches, MIFAO 129/3, Le Caire

Beaux, N., Karkowski, J., Majerus, E., Pollin, G. 2016: La chapelle d'Hathor. Temple d'Hatchepsout à Deir el-Bahari II. Façade et salles hypostyles, MIFAO 133, Le Caire

Beckerath, J. von 1999: Handbuch der ägyptischen Königsnamen, MÄS 49, Mainz a/Rhein

Bernhauer, E. 2002: Details zur Rekonstruktion der Hathorpfeiler vom Satet-Tempel auf der Insel Elephantine, MDAIK 58, 85-88

Bernhauer, E. 2003: Die Hathorkapitelle, [in:] Tietze, C. (Ed.), Rekonstruktion und Restaurierung in Tell Basta, Arcus: Berichte aus Archäologie, Baugeschichte und Nachbargebieten 6, Potsdam, 28-68

Bernhauer, E. 2005: Hathorsäulen und Hathorpfeiler: altägyptische Architekturelemente vom Neuen Reich bis zur Spätzeit, Philippika 8, Wiesbaden

Birkstam, B. 1974: Given Life Like Re Eternally - A Royal Epitheton, [in:] Brunnsaker, S., Nordström, H.A. (Eds), From the Gustavianum Collections in Uppsala, Boreas 6, Uppsala, 15-35

Biston-Moulin, S. 2012a: Remarques sur la transformation des épithètes $n f r \quad h p r(. w)$ dans les cartouches du nom de naissance de Thoutmosis III, Z̈̈S 139/1, 19-27

Biston-Moulin, S. 2012b: L'épithète $h k 3 \mathrm{~m}^{\top}{ }^{\mathrm{C}}(. t)$ et l'activité architecturale du début du règne autonome de Thoutmosis III, [in:] Gasse, A., Servajean, F., Thiers, C. (Eds), Et in Agypto et ad Egyptum. Recueil d'études dédiées à Jean-Claude Grenier, vol. 1, CENiM 5, Montpellier, 81-102

Biston-Moulin, S., Thiers, C. 2016: Le temple de Ptah à Karnak, vol. 1 : Relevé épigraphique (Ptah, nos 1-191), vol. 2: Relevé photographique (J.-Fr. Gout), BiGen 49, Le Caire

Bommas, M. 2000: Der Tempel des Chnum der 18. Dyn. auf Elephantine, unpublished $\mathrm{PhD}$ thesis, Universität Heidelberg, Heidelberg

Bonhême, M.-A., Forgeau, A. 1988: Pharaon, les secrets du pouvoir, Paris

Caban, M. 2015: Kapitele pilastrów kaplicy Hathor ze świątyni Dżeser achet Totmesa III w Deir el-Bahari / Capitals of pilasters from the Hathor shrine in the temple Djeser-akhet of Tuthmosis III at Deir el-Bahari, Architectus 3/43, 27-34

Caminos, R.A. 1998: Semna-Kumma II. The Temple of Kumma, ASEg 38, London

Carlotti, J.-F. 2005: Considérations architecturales sur l'orientation, la composition et les proportions des structures du temple d'Amon-Rê à Karnak, [in:] Jánosi, P. (Ed.), Structure and Significance. Thoughts on Ancient Egyptian Architecture, $D \ddot{O} A W W$ XXXIII, UZK XXV, Wien, 169-208 
Cénival, J.-L. 1964: Égypte. Époque pharaonique, Fribourg

Chapon, L. 2018a: Some Reliefs Representing the King in the Heb Sed Robe Discovered in the Henket-Ankh, EtudTrav XXXI, 123-143

Chapon, L. 2018b: Le Temple de Millions d'Années de Thoutmosis III. Étude du programme iconographique sur grès, unpublished $\mathrm{PhD}$ thesis, University of Granada, Granada

Chappaz, J.-L. 2014: Remarques sur l'architecture du Spéos Artémidos, [in:] Galán, J.M., Bryan, B.M., Dorman, P.F. (Eds), Creativity and Innovation in the Reign of Hatshepsut. Papers from the Theban Workshop 2010, SAOC 69, Chicago, 157-171

Czellár, K. 1981: Anthropomorphic supports in ancient Egyptian architecture, Periodica Polytechnica Architecture 25/1-4, 77-89

Daressy, G. 1926: Le voyage d'inspection de M. Grébauten en 1889, ASAE XXVI, 1-22

Dąbrowski, L. 1968: Temple d'Hatchepsout à Deir el-Bahari, $3^{\text {e }}$ terrasse, Projet de la reconstruction du mur ouest de la cour, EtudTrav II, 39-46

De Putter, T., Karlshausen, C. 1997: In search of the lost quarries of the Pharaohs, KMT 8/3, $54-59$

De Putter, T., Karlshausen, C. 2003: Provenance et caractères distinctifs des calcaires utilisés dans l'architecture du Moyen et du Nouvel Empire à Karnak, CahKarn 11, 373-386

Desroches-Noblecourt, C. 1990/1991: Le mammisi de Ramsès au Ramesseum, Memnonia I, 25-46

Dolińska, M. 1994: Some Remarks about the Function of the Thutmosis III Temple at Deir el-Bahari, [in:] Gundlach, R., Rochholz, M. (Eds), Ägyptische Tempel: Struktur, Funktion und Programm (Akten der Ägyptologischen Tempeltagungen in Gosen 1990 und in Mainz 1992), HÄB 37, Hildesheim, 33-38

Dolińska, M. 2015: Deir el-Bahari Temple of Tuthmosis III, Campaigns 2012-2013, PAM XXIV/1, 257-264

Epigraphic Survey 2009: The Epigraphic Survey, Medinet Habu IX: The Eighteenth Dynasty Temple, Part 1: The Inner Sanctuaries, with Translations of Texts, Commentary and Glossary, OIP 136, Chicago 2009

Gabolde, L. avec la colaboration de Gabolde, M. 1989: Les temples «mémoriaux » de Thoutmosis II et Toutânkhamon (un rituel destiné à des statues sur barques), BIFAO 89, 127-178

Gabolde, L., Gabolde, M. 2015: Les textes de la paroi sud de la salle des Annales de Thoutmosis III: Reconstitution architecturale et restitution épigraphique, [in:] Un savant au pays du fleuve-dieu. Hommages égyptologiques à Paul Barguet, Kyphi 7, $45-110$

Goyon, J.-Cl., Golvin, J.-Cl., Simon-Boidot, C., Martinet, G. 2004: La construction pharaonique du Moyen Empire à l'epoque gréco-romaine. Contexte et principes technologiques, Paris

Gundlach, R. 2001: Temples, [in:] OEAE 3, Oxford, 363-379

Haeny, G. 1997: New Kingdom 'Mortuary Temples' and 'Mansions of Millions of Years', [in:] Shafer, B.E. (Ed.), Temples of Ancient Egypt, Ithaca, 86-126 
Harrell, J.A. 2012: Building stones, [in:] Wendrich, W. (Ed.), UCLA Encyclopedia of Egyptology, Los Angeles, https://escholarship.org/uc/item/3fd124g0 (accessed May 31, 2012)

Harrell, J.A. 2016: Varieties and sources of sandstone used in Ancient Egyptian temples, Journal of Ancient Egyptian Architecture 1, 11-37

Harrell, J.A., Storemyr, P. 2009: Ancient Egyptian quarries, an illustrated overview, [in:] Abu-Jaber, N., Bloxam, E.G., Degryse, P., Heldal, T. (Eds), QuarryScapes: ancient stone quarry landscapes in the Eastern Mediterranean, Geological Survey of Norway, Special Publication 12, Trondheim, 7-50

Hayes, W.C. 1953: Scepter of Egypt. A Background for the Study of the Egyptian Antiquities in The Metropolitan Museum of Art I: From the Earliest Times to the End of the Middle Kingdom, Cambridge

Hornung, E. 1991: Sedfest und Geschichte, MDAIK 47, 169-171

Hornung, E., Staehelin, E. 1974: Studien zum Sedfest, AegHelv 1, Geneva

Hornung, E., Staehelin, E. 2006: Neue Studien zum Sedfest, AegHelv 20, Basel

Hölscher, U. with contributions by Anthes, R. 1939: The Excavation of Medinet Habu II:

The Temples of the Eighteenth Dynasty, OIP 41, Chicago

Iwaszczuk, J. 2016: Sacred landscape of Thebes during the reign of Hatshepsut. Royal construction projects. Volume 1. Topography of the West Bank, Travaux de l'Institut des Cultures Méditerranéennes et Orientales de l'Académie Polonaise des Sciences 2, Warsaw

Karkowski, J. 1980: An Archaeological Description of the Decoration of Osirid Pillars of the Upper Portico of the Temple of Hatshepsut at Deir el-Bahari, [in:] Krzyżanowski, L. (Ed.), The Temple of Queen Hatshepsut. Results of the Investigations and Conservation Works of the Polish-Egyptian Archaeological and Preservation Mission 1972-1973, Warsaw, 44-55

Karkowski, J. 2001: Dekoracja świątyni Hatszepsut w Deir el-Bahari / The Decoration of the Temple of Hatshepsut at Deir el-Bahari, [in:] Szafranski, Z.E. (Ed.), Królowa Hatszepsut i jej świątynia 3500 lat później / Queen Hatshepsut and her temple 3500 years later, Warsaw, 99-157

Karkowski, J., Wysocki, Z. 1975: Deir el-Bahari 1971-1972, EtudTrav VIII, 341-348

Kitchen, K.A. 1973: The Third Intermediate Period in Egypt (1100-650 B.C.), Warminster Lacau, P., Chevrier, H. 1956: Une chapelle de Sésostris I ${ }^{\text {er }}$ à Karnak, Le Caire

Laskowski, P. 2006: Monumental Architecture and the Royal Building Program of Thutmose III, [in:] Cline, E.H., O'Connor, D. (Eds), Thutmose III, A new Biography, Ann Arbor, 183-237

Leblanc, C. 1980: Piliers et colosses de type « osiriaques » dans le contexte des temples de culte royal, BIFAO LXXX, 69-89

Leblanc, C. 1997: Quelques réflexions sur le programme iconographique et la fonction des temples de «millions d'années », Memnonia 8, 93-105

Leblanc, C. 2010: Les Châteaux de Millions d'Années : une redéfinition à la lumière des récentes recherches. De la vocation religieuse à la fonction politique et économique, 
[in:] Leblanc, C., Zaki, G. (Eds), Les temples de millions d'années et le pouvoir royal à Thèbes au Nouvel Empire. Sciences et nouvelles technologies appliquées

à l'archéologie, Memnonia, Cahier supplémentaire 2, Le Caire, 46-53

Letellier, B., Larché, F. 2013: La cour à portique de Thoutmosis IV, EtudEg 12, Paris Lipińska, J. 1977: The Temple of Thutmosis III, Architecture, Deir el-Bahari II, Varsovie Marochetti, E.F. 2010: The Reliefs of the Chapel of Nebhepetre Mentuhotep at Gebelein (CGT 7003/1-277), CHANE 39, Leiden

MetMuseum: https://www.metmuseum.org/ (accessed April, 2020)

Murnane, W.J. 1981: The Sed Festival: A Problem in Historical Method, MDAIK 37, 370-376

Museum of Fine Art Boston: https://collections.mfa.org/collections (accessed April, 2020) Myśliwiec, K. 1985: Eighteenth Dynasty before the Amarna Period, IcRel XVI/5, Leiden Naville, E. 1898: The temple of Deir el-Bahari. Part III. End of Northern Half and Southern Half of the Middle Platform, MEEF 16, London

Naville, E. 1906: The Temple of Deir el-Bahari. Part V. The Upper Court and Sanctuary, MEEF 27, London

Naville, E.F., Clarke, S. 1910: The XIth Dynasty Temple at Deir el-Bahari II, MEES 30, London

Naville, E.F., Hall, H.R., Ayrton, E.R. 1907: The XIth Dynasty Temple at Deir el-Bahari I, MEES 28, London

Niedziółka, D. 1998: Inscriptions on the 32 Sided Columns of the Temple of Tuthmosis III at Deir el-Bahari, [in:] Eyre, C.J. (Ed.), Proceedings of the Seventh International Congress of Egyptologists, Cambridge, 3-9 September 1995, OLA 82, Louvain, $813-821$

Pecoil, J.-F., Baud, R., Beaux, N. 2000: L'Akh-menou de Thoutmosis III à Karnak. La Heret-ib et les chapelles attenantes. Relevés épigraphiques, Paris

Petrie, W.M.F. 1906: Researches in Sinai, London

Phillips, P.J. 2002: The Columns of Egypt, Manchester

Połoczanin, W. 1980: The Upper Portico of the Temple of Hatshepsut at Deir el-Bahari, [in:] The Temple of Queen Hatshepsut. Results of the Investigations and Conservation Works of the Polish-Egyptian Archaeological and Preservation Mission 1972-1973 2, Warsaw, 66-90

Połoczanin, W. 1985: The Composition of the Building Development of the Temple of Queen Hatshepsut in the Light of Investigations into Selected Sections of the Building, [in:] The Temple of Queen Hatshepsut. Results of the Investigations and Conservation Works of the Polish-Egyptian Archaeological and Preservation Mission Deir el-Bahari 3, Warsaw, 63-77

Redford, D.B. 1986: Pharaonic King-Lists, Annals and Day Books: A Contribution to the Study of the Egyptian Sense of History, SSEAP IV, Mississauga

Ricke, H. 1939: Der Totentempel Thutmoses' III, BÄBA 3/1, Kairo

Seco Álvarez, M. 2009: Recientes descubrimientos en el Templo Funerario de Tutmosis III, Boletín de Bellas Artes 37, 510-520 
Seco Álvarez, M. 2012: Trabajos Arqueológicos en el Templo de Millones de Años del Faraón Tutmosis III en Luxor, Campañas 2008-2011, Djeser 4, 64-73

Seco Álvarez, M. 2014: The Temple of Millions of Years of Tuthmosis III, EA 44, 21-25 Seco Álvarez, M. 2015: Latest news about the work of investigation in the Temple of Millions of Years of the pharaoh Thutmose III in Qurna, [in:] Seco Álvarez, M., Jódar Miñarro, A. (Eds), The temples of millions of years in Thebes, Granada, 101-133 Seco Álvarez, M., Martínez Babón, J. 2020: The Temple of Millions of Years of the Pharaoh Thutmose III (Luxor). An Update on the Research, EtudTrav XXXIII, 179-220

Seco Álvarez, M., Radwan, A. 2010: Egyptian-Spanish Project at the Temple of Thutmosis III in Luxor West Bank: Results of two Seasons, [in:] Leblanc, C., Zaki, G. (Eds), Les temples de millions d'années et le pouvoir royal à Thèbes au Nouvel Empire. Sciences et nouvelles technologies appliquées à l'archéologie, Memnonia, Cahier supplémentaire 2, Le Caire, 59-71

Seco Álvarez, M., Radwan, A., Martínez Babón, J., Alaeldine, A., Kamimura, E., Mora Ruedas, E., Moreno Cifuentes, M.A., Noureddine, I., Perzlmeier, C., Abu Ylazid, M.A., Karim, F.Y. abd el, Abu Zaid, O., Khairi Mohamed, F. 2010: First Season of the Egyptian-Spanish Project at the Funerary Temple of Thutmosis III in Luxor, ASAE 84, 27-61

Seco Álvarez, M., Radwan, A., Martínez Babón, J., Noureddine, I., Wilson, E., Guio, A., Kamimura, E., Gamarra Campuzano, A., Mora Ruedas, E., Moreno Cifuentes, M.A., Bader, B., Pazos, F., Karim, F.Y. abd el, Nouby, E. el, Khairi Mohamed, F. 2012-2013: Second and Third Excavation Season of the Egyptian-Spanish Project at the Mortuary Temple of Thutmosis III at the West Bank of Luxor (2009 and 2010), ASAE 86, 329-395

Stadelmann, R. 1979: Totentempel und Millionenjahrhaus in Theben, MDAIK 35, 303-321 Ullmann, M. 2002: König für die Ewigkeit. Die Häuser der Millionen von Jahren, Eine Untersuchung zu Königskult und Tempeltypologie in Ägypten, $\ddot{A} A T$ 51, Wiesbaden Weigall, A.E.P. 1906: A report on the excavation of the Funeral Temple of Thoutmosis III at Gurneh, ASAE VII, 121-141

Weigall, A.E.P. 1907: Plan of the Mortuary Temple of Thoutmosis III, ASAE VIII, 286 Wente, E.F., Van Sinclen III, C.C. 1976: A Chronology of the New Kingdom, [in:] Johnson, J., Wente, E.F. (Eds), Studies in Honor of George R. Hughes, SAOC 39, Chicago, 217-261

Wysocki, Z. 1980: The Upper Court Colonnade of Ḥatshepsut's Temple at Deir el-Baḥri, JEA 66, 54-69

Wysocki, Z. 1986: The Temple of Queen Hatshepsut at Deir el Bahari. Its Original Form, MDAIK 42, 213-228

Wysocki, Z. 1990: Deir el-Bahari, 1977-1982, EtudTrav XIV, 321-347

Wysocki, Z. 1992: The Temple of Queen Hatshepsut at Deir el Bahari: The Raising of the Structure in View of Architectural Studies, MDAIK 48, 233-254 


\section{ÉTUDES et TRAVAUX XXXIII / 2020}
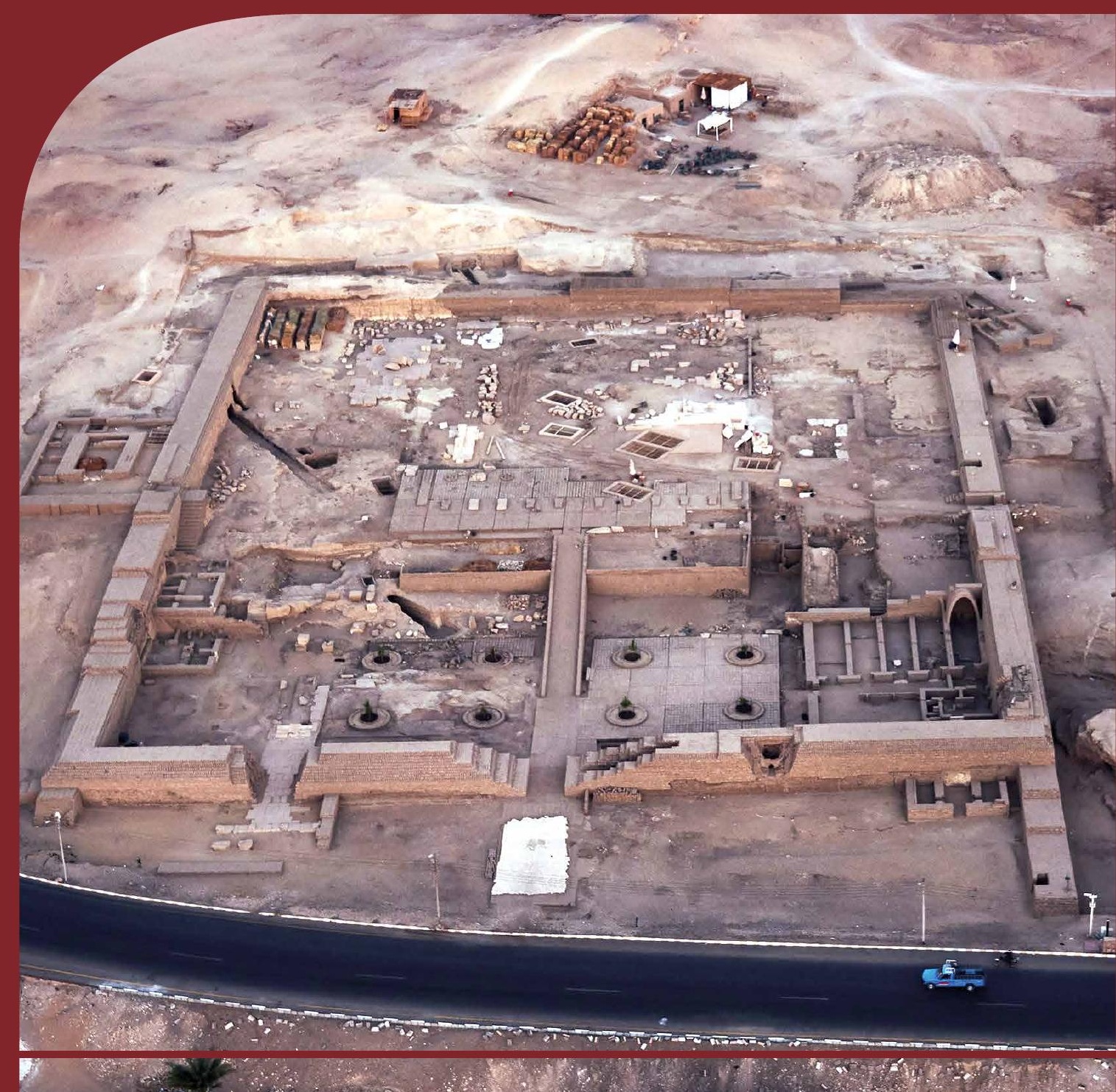

BOPIKSiO Institut des Cultures Mediterranéennes et Orientales IST PAN de l'Académie Polonáise des Sciences 


\title{
COMITÉ DE RÉDACTION SCIENTIFIQUE
}

Maciej Makowski - rédacteur en chef Jadwiga Iwaszczuk - rédacteur

Agnieszka Ryś - secrétaire de la rédaction

Ewa Laskowska-Kusztal - rédacteur thématique du volume

CONSEIL SCIENTIFIQUE DU JOURNAL

Michał Kobusiewicz (IAE PAN, Warszawa)

Ewa Laskowska-Kusztal (IMOC PAS, Warszawa)

Demetrios Michaelides (University of Cyprus, Nicosia)

Jean-Charles Moretti (IRAA-MOM, Université de Lyon 2/CNRS)

Dietrich Raue (Ägyptisches Museum der Universität Leipzig)

Paul Reynolds (ICREA, España)

Derek Welsby (British Museum, London)

COMITÉ SCIENTIFIQUE DE LECTURE

la liste des membres du comité est accessible en ligne sur

http://www.etudesettravaux.iksiopan.pl

\author{
RÉDACTION TECHNIQUE \\ Jadwiga Iwaszczuk \\ Maciej Makowski
}

REVUE DES TEXTES EN ANGLAIS

Jo Harper 
ÉTUDES et TRAVAUX XXXIII 
INSTYTUT KULTUR ŚRÓDZIEMNOMORSKICH I ORIENTALNYCH POLSKIEJ AKADEMII NAUK

\title{
STUDIA i PRACE
}

XXXIII

\author{
ROIKŚSiO \\ ESOPAN \\ WARSZAWA \\ 2020
}


INSTITUT DES CULTURES MÉDITERRANÉENNES ET ORIENTALES DE L'ACADÉMIE POLONAISE DES SCIENCES

\section{ÉTUDES et TRAVAUX}

XXXIII

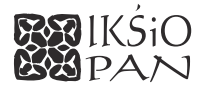

VARSOVIE

2020 
Publication scientifique financée dans le cadre du programme du Ministre de la Science et de l'Éducation Supérieure

« Programme National de Développement de l'Humanistique » pour les années 2016-2021 (projet no 3bH 150099 83)

\title{
UARODOWY PROGRAM ROZWOJU HUMANISTYKI
}

\author{
Copyright (C) \\ Instytut Kultur Śródziemnomorskich i Orientalnych PAN \\ et les Auteurs \\ Warszawa 2020
}
ISSN 2084-6762
(jusqu'en 2011 : 0079-3566)
e-ISSN 2449-9579
Version première en papier, imprimée en Pologne - 150 copies
Version électronique accessible sur
http://www.etudesettravaux.iksiopan.pl

Édition: Polskie Towarzystwo Historyczne et Wydawnictwo Neriton, Warszawa

Conception générale de la couverture : J. Iwaszczuk

Photographie de couverture : J. Pablo Moreira (C) Thutmosis III Temple Project

(Henket-ankh, le temple des Millions d'Années de Thoutmosis III, Louxor) 


\section{Table des matières}

Editorial (par Ewa Laskowska-Kusztal) ................................................................... 7

MirosŁaW BARWIK

Two Portraits of Senenmut in the Hatshepsut Temple at Deir el-Bahari

MirosŁaW BARWIK

New Prayers and Invocations to Hathor among Unpublished Dipinti

from the Thutmose III Temple at Deir el-Bahari

LiNDA CHAPON

The Decoration of the Columns and Pillars from the Henket-ankh of Thutmose III

(Western Thebes)

Abraham I. Fernández Pichel

Quelques blocs ptolémaïques inédits de la cour du IX pylône du domaine

d'Amon à Karnak

Amgad Joseph

The Stela of Haremwia, Chief of the Provisioning Sector of the Temple Workshop

(CG 34079 / JE 22011)

EWA JÓZEFOWICZ

Ramesside Inscriptions and Preparatory Sketches in the Western Wall of Portico

of Obelisks of Hatshepsut's Temple at Deir el-Bahari

Miral LASHIEN

Donkeys in the Old and Middle Kingdoms According to the Representations

and Livestock Counts from Private Tombs

AleKsandra Pawlikowska-Gwiazda

Christian Secondary Epigraphy in the Temple of Hatshepsut. Some New Remarks

KRZYSZTOF RADTKE

Square Grids in the Tomb of Akhethotep - Questions and Doubts

Myriam Seco Álvarez, JaVier Martínez Babón

The Temple of Millions of Years of the Pharaoh Thutmose III (Luxor). An Update on the Research 